\title{
Social Entrepreneurship: Objectives, Innovation, Implementation and Impact on Entrepreneurship
}

\author{
Anele MTHEMBU and Brian BARNARD* \\ WITS Business School, The University of the Witwatersrand, South Africa
}

\begin{abstract}
The study examines social entrepreneurship from the perspective of: objective and philosophy (why social entrepreneurs are social entrepreneurs), opportunity identification (how social entrepreneurs recognise opportunities), implementation (how social entrepreneurship is implemented), and social entrepreneurship's contribution to entrepreneurship. The dual objective (some profit, social impact), and strong focus on social impact of the social entrepreneur are highlighted. Although certainly possible, opportunities are encountered and experienced, and thus recognised, rather than actively sought. There are both strong similarities and differences between social entrepreneurship and entrepreneurship opportunities. Innovation is as much a component of social entrepreneurship. Also, the proactiveness and innovativeness of social entrepreneurship are important aspects and concepts. Social entrepreneurship can also be radical and disruptive. Implementation of social entrepreneurship entails both the micro- and macro-level. Both the individual implementation of social entrepreneurship, and the overall extent and sophistication of social entrepreneurship opportunities and practice at a broader level, are relevant. Sustainability is a very important consideration for the social entrepreneur. Emphasis has shifted to self-sufficiency and financial sustainability. There are marked similarities between start-up for the social entrepreneur, and the entrepreneur, particularly given that social enterprises are run as businesses just as much. The various contributions of social entrepreneurship to entrepreneurship are highlighted. It is evident that social entrepreneurship and entrepreneurship can be compared on several grounds, including the level of risk and the level of difficulty.
\end{abstract}

Keywords: social entrepreneurship, entrepreneurship, opportunity, opportunity identification, implementation, social impact, economic development.

JEL Classification: O30, L26

\section{Introduction}

Social entrepreneurship is not a new phenomenon (Dees, 2001), and is increasingly becoming more relevant. Social entrepreneurship is also becoming more self-sufficient and innovative, although more effort is

\footnotetext{
*Corresponding Author:

Brian Barnard, Wits Business School, University of the Witwatersrand, South Africa

Article History:

Received 3 April 2019|Accepted 5 July 2019 | Available Online 30 July 2019

Cite Reference:

Mthembu, A. and Barnard, B., 2019. Social Entrepreneurship: Objectives, Innovation, Implementation and Impact on Entrepreneurship. Expert Journal of Business and Management, 7(1), pp.147-177.

This paper has previously been included in an open access repository - SSRN.
} 
required to build social entrepreneurship-related innovation theory (Certo and Miller, 2008; Harding, 2004; Johnson, 2000; Mulgan, 2006). As an entrepreneurial discipline, social entrepreneurship has a distinct focus on transforming society, creating social value, dealing with social problems, and improving society (AbuSaifan, 2012; Hartigan, 2006; Drayton, 2002; Johnson, 2000; Roberts and Woods, 2005).

Given its particular focus, social entrepreneurship offers an unique perspective on opportunity and opportunity recognition, and therefore entrepreneurship (Robinson, 2006). Moreover, a principal question as to what extent social entrepreneurship shapes or can shape conventional entrepreneurship, remains. Perspective is essential for innovation, and given its social focus, social entrepreneurship may offer a new and unique outlook. What remains to be seen is whether entrepreneurship can look to social entrepreneurship for a fresh perspective, and for new ways to innovate, and whether entrepreneurship can learn from social entrepreneurship.

The purpose of this study is to further examine social entrepreneurship, and to note how it informs conventional entrepreneurship and opportunity recognition. To that end, the following aspects are investigated further: the objectives of social entrepreneurship, innovation practices of social entrepreneurs, implementation within social entrepreneurship, and the relationship between social entrepreneurship and entrepreneurship.

The research addresses the following research question: how does social entrepreneurship and social entrepreneurial practice inform ordinary entrepreneurship and opportunity recognition? The following subquestions are explored:

- What are the objectives of social entrepreneurship? How does social entrepreneurship thinking relate to entrepreneurship?

- How do social entrepreneurs identify opportunities and incorporate innovation? How does it relate to and compare with entrepreneurship?

- How is social entrepreneurship implemented? How does it relate to and compare with entrepreneurship?

- What is the relationship between social entrepreneurship and entrepreneurship? How does social entrepreneurship contribute to entrepreneurship? How do social entrepreneurs perceive their competencies as ordinary entrepreneurs?

The study expands the understanding of social entrepreneurship and entrepreneurship, and contributes to the literature on social entrepreneurship, entrepreneurship, opportunity and opportunity recognition.

The study mostly focuses on experienced social entrepreneurs, and predominantly investigates their perceptions regarding social entrepreneurship. Experienced entrepreneurs will have developed deep perceptions regarding social entrepreneurship. No particular attention is paid to industry, and sampling is not constrained according to industry.

\section{Literature Review}

\subsection{Defining Social Entrepreneurship}

2.1.1. Context

Dees (2007) notes that, to put the current interest in social entrepreneurship in perspective, human history can be thought of as a series of experiments in social organisation, responding to the question of how we, as humans, ought to organise ourselves in order to move closer to the ideals of a good society. Although over time a mixed religious and secular society has continued to evolve and complement government-based efforts to tackle poverty, government has, for the most part, been the hope for social problem solving. Government, as a social problem solver, has led to some notable successes in the past, such as increased access to education and healthcare. However, it has also had its limitations.

Dees (2001) argues that while the language of social entrepreneurship may be new, the phenomenon is not. Social entrepreneurs have always been around, although they have not been called as such. Social entrepreneurship is not limited to innovative not-for-profit ventures, but can include social purpose business ventures and hybrid organisations that blend not-for-profit and for-profit elements.

Austin et al. (2006) note that there are various definitions of social entrepreneurship. Despite differences in definitions, the underlying driver is to create social value, characterised by innovation or the creation of something new. Social entrepreneurship is primarily driven by the social problem being addressed, and a social enterprise should take a format that mobilizes the resources needed to address that problem most effectively. Social entrepreneurship can therefore follow different avenues. 


\subsubsection{Social Health and Transformation}

Social entrepreneurship transforms society, deals with social problems, and improves society (AbuSaifan, 2012; Hartigan, 2006; Drayton, 2002; Johnson, 2000; Roberts and Woods, 2005).

Roper and Cheney (2005) argue that central to any discussion of social entrepreneurship, are the questions concerning who should, and who can take responsibility for the needs of civil society. Further to that, ideological questions regarding the continuance and health of a civil society, distinct from political and economic sectors, also emerge.

Johnson (2000) notes that, as public funding becomes scarce, social entrepreneurship is emerging as an innovative approach for dealing with complex social needs.

Drayton (2002) points out that social entrepreneurs identify something in society that is stuck and not working, and envision a systematic change that will allow them to effect a shift towards improving society.

It is argued that social entrepreneurship entails constructing, evaluating, and pursuing opportunities for transformative social change, effected by visionary, passionately dedicated individuals (Abu-Saifan, 2012; Hartigan, 2006; Roberts and Woods, 2005).

Social entrepreneurs are defined as individuals or private organizations, who have vision for society, and the ability to develop innovative ways of dealing with and alleviating social problems in their communities (Alvord et al., 2004; Korosec and Berman, 2006).

Thompson et al. (2000) describe social entrepreneurs as people who channel resources to social problems or opportunities not met by the welfare system.

\subsubsection{Model and Culture}

There appears to be varying views describing the model and culture of social entrepreneurship. Boschee and McClurg (2003) argue that the culture of a traditional non-profit, irrespective of how innovative it is, differs immensely from the culture of an entrepreneurial non-profit. Dees (2007) notes that social entrepreneurs often use the legal form of organization of charities or non-profits, although they do not necessarily see themselves as such. Bornstein (2004) describes social entrepreneurs simply as "people who solve social problems". Harding (2004) argues that social entrepreneurs are orthodox businesses with social objectives, who principally re-invest their surpluses for that purpose in the business or in the community, as opposed to maximizing shareholder and owner profits. Dees (1994) defines social enterprises as private organizations committed to solving social problems, and by so doing, serve the disadvantaged, and provide socially important goods that were inadequately provided by public agencies or private markets.

Boschee (1998) views social entrepreneurs as not-for-profit executives who are able to strike a balance between pursuing their profit motives and moral imperatives. Harding (2004) on the other hand, notes that social entrepreneurs recognise a part of society that is stuck, to which they respond by providing new and innovative ways to get it unstuck. By so doing, they act as change agents in the social sector.

\subsubsection{Process and System}

Light (2006) views a social entrepreneur as an individual, group, network, organization, or alliance of organizations, that seeks sustainable, large-scale change through pattern-breaking ideas in the way in which governments, non-profits, and businesses address significant social problems. Social entrepreneurship, as a process, involves the recognition, evaluation, and exploitation of opportunities that result in social value (Certo and Miller, 2008).

\subsection{Purpose and Impact}

\subsubsection{Social (health) Organization and Governance}

Dees (2007) argues that a cursory look at world affairs should convince any thinking and caring person, regardless of political ideology, that there is considerable room for improvement. Despite considerable improvements in the quality of life achievement by humankind in the past two centuries, still many persistent problems remain, and new ones emerge. Although there has been rapid economic growth and experiments with activist governments, a large portion of the world population remains poverty stricken. Irrespective of our different visions of an ideal world, the gap between reality and our notions of the ideal remains enormous. Encouraging and supporting social entrepreneurs is a potential promising strategy for improvement.

According to Mulgan (2006), the process of social innovation remains under-studied, whilst the processes of commercial innovation have been the subject of considerable academic research. The author points to severe innovation deficits and notes that much of the solution associated with these issues lies in social organization.

Dees (2007) states that, in the same way that high levels of biodiversity (differentiation) and 
entrepreneurship characterize a vibrant ecosystem, so should high levels of social entrepreneurship come to characterize a healthy society. Benefits of social entrepreneurs over government include greater flexibility and adaptability, lower risk, greater diversification, and increased efficiency or legitimacy.

Dacin et al. (2011) argue that over the last decade, social entrepreneurship has become an increasingly important international cultural phenomenon. Its growing appeal has been particularly welcomed by a group of socially aware people who want to see change.

\subsubsection{Socio-Economic Development}

Mair and Noboa (2006) note that social entrepreneurship employs innovative approaches to tackle social issues in areas such as education, and human rights. In addition, it forms an important building block in the sustainable development of countries. The aim of social entrepreneurship is to create viable socio-economic structures, relations, institutions, organizations and practices, that yield and sustain social benefits.

Mair and Marti (2006) argue that the nature of the social needs and social change addressed by social entrepreneurs differs, depending on the context - the context depicts the problems and focus.

Harding (2004) points out that public services are delivered more efficiently, which is good for the economy, and society benefits when not-for-profit organizations become more self-efficient and rely less on grants. The world's investors are becoming more interested in a broader definition of business value creation, and policy makers are more interested in the role entrepreneurship plays in boosting economic growth. In the same light, the role that social enterprise plays in creating economic and social value, ought to be examined more closely.

Harding (2004) comments on the economic impact of social entrepreneurship, and notes the following: Research findings suggest that all forms of socially oriented organization create more jobs on average than the other two forms (mainstream entrepreneurial enterprises, and those categorised by mixed revenue streams). In addition, pure sales have higher turnover per employee, in comparison to mainstream businesses in the Global Entrepreneurship Monitor sample. Social enterprises with mixed revenue, however, create five times as many jobs, and a little over six times the amount of turnover, as mainstream entrepreneurial businesses. It so happens that women are most likely to be engaged in this group.

\subsubsection{Social Change and Transformation}

Mair and Marti (2006) note that some researchers view social entrepreneurship as a means to alleviate social problems and catalyze social transformation. They argue that social entrepreneurship catalyzes social transformation, by meeting social needs.

Mair and Marti (2006) highlight the research focus efforts: 1) political opportunities and threats; 2) resource mobilising structures and active appropriation of sites for mobilisation; 3 ) collective action frames and identity formation; and 4) established repertoires of contention and innovative collective action by challengers and their member opponents, all which are underpinned by the desire to effect social change.

Dacin et al. (2011), and Short et al. (2009), note that institutional entrepreneurship in influential organizations has been driven by the sharing of anecdotal stories of the heroic deeds of ordinary people. Another way that this has been used to stir social responsibility (as a response to pressures in the external environment), is through the adoption of policies that influence a collectivist orientation, with a benefit that goes beyond a benefit derived by the individual. Expressed differently, Short et al. (2009) view the social entrepreneur as the underlying and indirect force of change executed by the private sector, having a positive ripple effect on the public sector agenda.

\subsubsection{Social Equity}

Dees (2001) notes that markets have a way of not working well for social entrepreneurs. Markets don't always serve social value or social health.

Boschee and McClurg (2003) state that social entrepreneurs' earned income strategies being tied to their mission, is what sets them apart. They either employ people with various disadvantages or disabilities, or they sell mission-driven products and services that directly impact a specific social problem. While profitability remains a goal, it is not the sole objective, as profits are re-invested in the mission, as opposed to being distributed to shareholders, thereby achieving a double bottom line (realising financial and social returns).

\subsubsection{Social Value}

Abu-Saifan (2012) states that the interest in social entrepreneurs stems from their role in addressing a multitude of critical social problems, and their role in improving the quality of life of those affected.

Auerswald (2009) notes that while social entrepreneurs and conventional entrepreneurs both generate 
new, disruptive models for organizing human activity, the difference lies in that conventional entrepreneurs' focus is creating financial value, whereas social entrepreneurs' focus is creating social value. Social entrepreneurs therefore challenge the status quo, and solve critical social challenges. Put another way, Mair and Marti (2006) view and define social entrepreneurship as a process of combining resources in new ways, to create social value, by exploring and exploiting opportunities, with the aim of meeting social needs.

According to Marti and Marti (2006), social entrepreneurship has its historical precedents from Victorian industrialists, who combined commercial success with social progress.

Short et al. (2009) state that the primary characteristic of public and non-profit research is the inherent interest in fostering social improvements in society. Non-profit research has examined charitable organisations, such as the United Way and the Red Cross. These organizations reduce social ills, provide social goods that are inadequately supplied by the marketplace, supplement government activities, and strengthen communities.

\subsubsection{Efficiency}

Auerswald (2009) argues that the actions of entrepreneurs not only create private value through the provision of goods and services, and social value by improving the efficiency of markets and governments, an additional important dimension of entrepreneurship and value creation to consider relates to equity, as opposed to efficiency.

Austin et al. (2006) highlight the theory that explains how social-purpose organizations emerge - that it is due to social-market failures. Often, it is a result of those needing the services, not being able to afford them. Consequently, social entrepreneurs find opportunities, where commercial entrepreneurs experience problems. As noted by Short et al. (2009), much research still needs to be conducted in order to gain future theoretical insights into understanding the unique role social innovations play in disrupting competition in the greater market, even though commercial enterprises continue to engage in entrepreneurship initiatives.

\subsection{Uniqueness of Social Entrepreneurship}

Dacin et al. (2010) evaluate definitions of social entrepreneurship, and compare social entrepreneurship to other forms (conventional, organizational, cultural), and conclude that it is not a distinct type of entrepreneurship.

\subsubsection{Similarities between Entrepreneurship and Social Entrepreneurship}

Austin et al. (2006) point out that the distinction made between social entrepreneurship and commercial entrepreneurship, with regards to their purpose viz. creating social value versus creating profitable operations resulting in private gain, is an over-statement. To the contrary, commercial entrepreneurship benefits society by providing new and valuable goods, services, and jobs, and can also have transformative social impacts, so much so that some commercial entrepreneurs may use such transformations as their main motivation. Abu-Saifan (2012) notes that, as part of its Entrepreneurial Design for Extreme Affordability course, Standford University launched Social E Lab (socialelab.org) in 2004, to promote the use of entrepreneurship principles to solve social and environmental problems. Through that program, a number of other successful projects were developed, including DripTech (driptech.com), Project Healthy Children (projecthealthychildren.org), and Embrace (embraceglobal.org).

\subsubsection{Differences between Entrepreneurship and Social Entrepreneurship}

Massetti (2008) notes that social entrepreneurs and entrepreneurs differ along two continuums, namely 1) the nature of the mission the entrepreneurs select for their businesses, and 2) the extent to which profits are required to operate the business. Their focus differ in that social entrepreneurs are concerned with social issues, whereas traditional entrepreneurs are concerned with market-orientated ones. Social entrepreneurs need to have profits to successfully function, and their profits are used to support social causes, rather than to increase the wealth of shareholders, managers, and owners - distinctions from traditional not-for-profit institutions, and traditional profit-based businesses, respectfully.

Mair and Marti (2006) argue that, rather than profit versus not-for-profit, the main difference between entrepreneurship in the business sector and social entrepreneurship, lies in the relative priority given to social wealth creation versus economic wealth creation. A distinguishing feature of social entrepreneurship is the limited ability in which the value created is captured. This issue is highlighted by the inability of social entrepreneurs, who address basic social needs, to capture economic value, because their "customers" are often unable to pay for those products and services, even if they are willing to.

Short et al. (2009) argue that conceptual development in social entrepreneurship may provide an unique context for integrating strategy and entrepreneurship research, by enhancing understanding of how 
organizations simultaneously create social value and achieve competitive advantages.

Austin et al. (2006) state that social entrepreneurs are unable to tap into the same capital markets generated by commercial entrepreneurs, due to non-distributive restrictions on surpluses generated by nonprofit organizations, and the embedded social purpose of for-profit or hybrid social enterprises. Furthermore, it is difficult to compensate staff of a social entrepreneurship venture.

Differences in measuring performance: Austin et al. (2006) point out that it is far more difficult to measure performance of social purpose for the social entrepreneur, as opposed to the commercial entrepreneur who can use tangible and quantifiable measures of performance.

Differences in innovation: Although innovation is recognized as a key theme in social entrepreneurship, more effort is required to build social entrepreneurship-related innovation theory (Short et al., 2009).

Differences in opportunities: Austin et al. (2006) note that the primary focus differs for commercial and social entrepreneurship, namely economic returns and social returns, respectively. Conceptually, opportunities appear similar across commercial and social entrepreneurship; however, in practice this is not the case, due to fundamental differences in missions and responses to market failure. Due to underlying differences in objectives, opportunities are evaluated differently.

Differences in risk: Risk taking by social entrepreneurs has been a necessary consideration for scholars, with two arguments posited by Short et al. (2009): The one is based on the logic theory, which suggests that social entrepreneurs are more risk averse than commercial entrepreneurs, given the former's concern with the survival of the enterprise. What remains to be examined, empirically, is entrepreneurial orientation.

There are essential differences between an entrepreneurial business model for a non-profit - where the entrepreneur takes on risk - and social entrepreneurship, where risk is taken on behalf of a group, for the benefit of a group (Clark and Brennan, 2012).

Differences in value: Auerswald (2009) examines the differences in the value generated through a private entrepreneurial endeavour, and one with the intent of bearing an impact socially. The author argues that social value is not limited to the externalities found with private entrepreneurial endeavours: the benefit in social entrepreneurship exceeds the general gains of market activity. The impact of the gains must translate in the reduction of costs to society, addressing social needs and problems.

The benefit accruable to commercial entrepreneurs - being the surplus in consumer value and producer value - is what attracts market participants (Auerswald, 2009). However, for the social entrepreneur, reputational and ethical value are principally reaped, enabling them to charge a premium on their goods or services (Auerswald, 2009).

Auerswald (2009) argues that value creation has an important ethical dimension to it. As consumer surplus relates to a consumer's willingness to pay for a specific good, income is a prerequisite. Social value which overlooks the income dimension, is human capability. The creation of human capability can thus differentiate social entrepreneurs from other types of entrepreneurs. In this way, the value created by social entrepreneurs need not manifest in the markets. In some instances, the work of social entrepreneurs can bypass the markets, and enhance human capability, increasing freedom or deepening social trust. An example is the restoration of sight.

Differences in resources: Social entrepreneurship has a different approach to resource utilisation (Dacin et al., 2010). Resources utilised include relational, cultural and institutional.

\subsection{Opportunity}

Certo and Miller (2008) state that entrepreneurs have an ability to recognise and be aware of supply or demand of a value-creating product or service. Social entrepreneurs recognise social needs and then use innovation (applying a new technology or approach) to create social value.

\subsubsection{Nature of Opportunity}

Robinson (2006) notes that since social entrepreneurial opportunities are embedded in a social sector market (the sector, the independent sector or the citizen sector), it makes them a special case of opportunities. It forms part of the economy that provides social services and products to communities, with direct social or environmental (or both) benefits. Participants in this sector include: governmental agencies, non-governmental organizations, private companies, and private citizens. Social sector markets are defined by two characteristics, namely: 1) their social nature, and 2) they are highly influenced by formal and informal social and institutional factors. Social sector markets are often geographical areas where a specific problem persists, thereby making social sector markets challenging, as they typically arise from situations where the formal and informal 
economies occur concurrently.

Guclu et al. (2002) point out that, to cater for different values and social needs, the entrepreneur ensures initial viability through adequate alignment.

\subsubsection{Opportunity Recognition}

Robinson (2006) states that previous knowledge, and perception of barriers affect opportunity recognition. Experience will influence how an entrepreneur perceives opportunities, and how they perceive an entry barrier. Experience for an entrepreneur has two dimensions: business and social.

Robinson (2006) considers economic barriers, social entry barriers, institutional barriers, and cultural barriers. Economic entry barriers relate to investments in the business, that would provide resources and technology, in turn that would give the company its competitive edge. Social entry barriers exclude the entrepreneur from utilizing existing social network relationships within the market. Institutional entry barriers prevent the entrepreneur from gaining knowledge about the rules, norms and values that contribute to the culture, order and practices of a particular market. Cultural entry barriers relate to informal institutions such as language, dress and etiquette, which are often critical to a firm's success in securing the goodwill and trust of stakeholders.

Robinson (2006) argues that because social entrepreneurial opportunities are highly influenced by the social and institutional structures in a market or community, it makes them different from other types of opportunities. Social and institutional structures therefore impact opportunity recognition.

Mulgan (2006) states that innovation is brought about by an idea of a need that isn't being met, together with an idea of how that need could be met. Needs can be highlighted through various channels, for example angry individuals and groups, campaigns, political movements, careful observation, or even through informal social movements, religious movements, and existing voluntary organisations.

\subsubsection{Types of Opportunity}

Short et al. (2009) note that there are two leading perspectives in opportunity research that could inform social entrepreneurship research. According to the opportunity creation theory, the opportunity is not independent of the entrepreneur. It asserts that entrepreneurs act and observe the effects of their actions, as opposed to searching for opportunities. This has not been found in social entrepreneurship literature to date. The second theory, the discovery theory, presupposes that opportunities exist out there, and it is the entrepreneur's responsibility to find and exploit them.

Hockerts (2006) points out that social purpose business ventures as an emerging social innovation, is viewed as a business opportunity which creates new market space, while also attaining a social objective, as it is turned into a commercial for-profit business. Examples of such include: The Body Shop, and Whole Foods Market. The author lists activism, self-help, and philanthropy as the three sources of social entrepreneurial opportunity that can explain the existence of social purpose business ventures. Hockerts (2006) notes that the aim of activists is to influence politicians and managers, through campaigns that are confrontational and sometimes cooperative in nature. Some activist groups, however, have realized that the best way to meet their goals could be through the support of social purpose enterprises, and have since started to explore that route. Social entrepreneurs may find a lot of opportunity (partnering and cooperating) with activist groups. Hockerts (2006) states that the beneficiaries of the social enterprise are a second source of social entrepreneurial opportunity. Self-help as a source of entrepreneurial opportunity can provide the enterprise with valuable resources, thereby providing a source of opportunity for social enterprises. Social entrepreneurs can also find opportunities with philanthropists.

Mulgan (2006) states that social innovation can be viewed as social change been driven by a very small number of heroic, energetic, and impatient individuals, who remade the world by persuading and cajoling the lazy and timid majority into change. Another view is that individuals are not the originators, but rather carriers of ideas. Movements of change stem from ideas of discontent, although their histories appear to be very different. Social change is very complex, however neither view adequately explains its complexities.

Zahra et al. (2009) argue that one of the greatest skills of many social entrepreneurs, is their ability to inspire, marshal and mobilize the efforts of commercial and non-commercial partners, donors, volunteers and employees, in the pursuit of social wealth. In order to succeed, it is often important to have built collaborative relationships that will execute social initiatives. While other social entrepreneurs might be more adept at creating organizations that tackle social issues, some place more focus on local issues.

Zahra et al. (2009) list three types of social entrepreneurs: Social Bricoleur, Social Constructionist, and Social Engineer. Social bricoleurs discover and address small-scale local social needs. Social Constructionists fill gaps to under-served clients created by market failures, thereby introducing reforms and 
innovations to the broader social system. Social Engineers, on the other hand, identify existing social structures which have systemic problems, and they address them by introducing revolutionary change. Because of their large scope and scale of ambitions, coupled with the lack of legitimacy they might face, Social Engineers require popular support to fulfill their missions. They therefore require the ability to gather sufficient political capital, to assemble the necessary resources they need and achieve legitimacy, in order for them to act accordingly.

Guclu et al. (2002) note that ideas commonly have their roots in the personal experience of the entrepreneur, but they are not limited to personal experience. Other factors, including recognising social needs, social assets, and change, can also stimulate social entrepreneurs to generate ideas worth exploring and developing.

\subsubsection{Innovation}

Mulgan (2006) states that the expanding field of research on business innovation has obvious relevance to social innovation. The author goes on to list some of the steps of social innovation: 1) generating ideas by understanding needs, and identifying potential solutions, 2) developing, prototyping, and piloting ideas, 3) assessing, scaling up, and diffusing good ideas, and 4) learning and evolving.

Robinson (2006) points out that social entrepreneurship has the potential to bring an interdisciplinary array of actors together, which has the potential to lead to various boundary-spanning research and practical activities. The result of such boundary-spanning is the hybridization of organizational forms and norms.

Mulgan (2006) argues that some of the most effective methods for cultivating social innovation start from the presumption that people are competent interpreters of their own lives, and competent solvers of their own problems. Individuals or institutions seeking to find answers to peoples' problems, may do best by finding out how the people are themselves solving their own problems. The individuals themselves are a source of opportunity, and they already possess solutions to their own problems. Needs are then tied to new possibilities that may be based on technology, organization, or knowledge. Ideas seldom emerge fully formed. Often, the social entrepreneur will quickly set up an embryonic organization as a prototype or pilot, and then galvanize enthusiasm for it.

Mulgan (2006) states that for social innovation to happen, the right background conditions must be present. Key conditions include legal protections and status, as well as open media. In business, drivers of social innovation include competition, open cultures, and accessible capital, whereas hindrances could come from monopolization of capital by urban elites or government. Conditions in politics and government include competing parties, think tanks, innovation funds, contestable markets, many pilots, as well as creative leaders. Acceleration of social innovation in social organizations is aided by practitioner networks, allies in politics, strong civic organizations, such as trade unions and hospitals, and the support of progressive foundations and philanthropists. An universal theme in all these fields is that global links make it easier to learn lessons, and share the widely spread ideas at an early stage.

Mulgan (2006) points out that most innovations in business and technology fail, as do most social innovations. At times there are valid reasons for failure, and they include: cost, an unwanted idea, an idea that may be insufficiently useful, not good enough relative to alternatives, or flawed by unforeseen side effects. However, inherent flaws are not the main reason for failure, but a lack of mechanisms to promote, adapt, and scale up the ideas.

\subsubsection{Evaluation and Measurement}

Dees (2001) notes that it is inherently difficult to measure social value creation. Scholars have attempted to measure the social wealth standard of social entrepreneurship (Zahra et al., 2009). This has, however, been difficult to accomplish, on account of the wide variation of products and services, which are largely subjective in nature (Zahra et al., 2009).

Dees (2001) argues that, because market discipline does not automatically weed out inefficient or ineffective social ventures, social entrepreneurs take steps to assure they are creating value. They do this by seeking a sound understanding of the constituencies they are serving - social entrepreneurship remains customer focused.

Clark and Brennan (2012) note some of the criteria used by foundations and non-profits that provide support to entrepreneurs. Ashoka (www.ashoka.org) provides funding to fellows based on the following five criteria: 1) the knockout test: a new idea; 2) creativity; 3) entrepreneurial quality; 4) social impact; and 5) ethical fiber. The Schwab Foundation (www.schwabfound.org) uses innovation, sustainability, and direct social impact as their quantifiable criteria.

Zahra et al. (2009) note that, by applying traditional business and market-orientated models, social 
entrepreneurship is able to offer innovative solutions to complex and persistent social issues.

Zahra et al. (2009) state that Total Wealth $(\mathrm{TW})=$ Economic Wealth $(\mathrm{EW})+$ Social Wealth $(\mathrm{SW})$. Further, TW $=\mathrm{EW}+\mathrm{SW}$, where EW = Economic Value $(\mathrm{EV})-$ Economic Costs $(\mathrm{EC})-$ Opportunity Costs $(\mathrm{OC})$; Social Wealth $(\mathrm{SW})=$ Social Value $(\mathrm{SV})-$ Social Costs $(\mathrm{SC})$. As a result, $\mathrm{TW}=\mathrm{EV}+\mathrm{SV}-(\mathrm{EC}+\mathrm{OC}$ $+\mathrm{SC})$.

\subsubsection{Process}

Borins (2000) suggests that improved service and lower costs are achieved by entrepreneurial public innovators, by them developing a clear vision, maintaining focus on social goals, proactively solving problems, and ethically overcoming obstacles, in-so-doing adding social value.

Guclu et al. (2002) state that as long as action and research are grounded in a set of plausible hypotheses concerning the underlying social impact theory and business model, which includes an effective operating model and a viable resource strategy, the chance of success is significantly increased.

Guclu et al. (2002) state that every new venture idea is implemented in a distinctive operating environment. Assumptions about the markets, industry structure, the political environment, and the culture, will be made by most ventures. Markets refer to the intended users or clients, as well as the third party payers, donors, volunteers, and workers, therefore, social entrepreneurs ought to have a plausible value proposition for each market or stakeholder group. Within the industry structure are alternative providers, potential collaborators or partners, crucial complementary services, potential substitutes, and key suppliers. Specific requirements, and various potential sources of public support or resistance, form part of the political environment. The culture is defined by the dominant values of the people in the intended operating environment, as well as the behavioural norms and relevant sub-group cultures. Due to the dynamic nature of the operating environment, social entrepreneurs need to be sensitive to the window of opportunity. Furthermore, as social entrepreneurs develop their ideas into worthwhile opportunities, they need to consider personal fit, explained by the three categories: 1) commitment, 2) qualifications, and 3) stage of life.

\subsection{Context and Environment}

Mair and Noboa (2006) argue that the background of the social entrepreneur is critical for triggering the desirability of launching a social enterprise. In that regard, the intentions aimed at fulfilling a social objective are backed by the entrepreneur's social, moral and educational background. In addition, previous entrepreneurial experience is also an important aspect in understanding social entrepreneurship as a process. Self-efficacy and social support are important elements, as they "enable" the entrepreneur to see the social venture as something feasible. The context in which social entrepreneurs find themselves, allows them to recognize social opportunities, and has the effect of turning them into altruistic citizens who are unsatisfied with the status quo, are loyal to their values and philosophy, motivated to be socially responsible, and they value the respect, success and lifestyles of their fellow social entrepreneurs. Social entrepreneurs have a hightened level of loyalty to their values and philosophy, and their moral judgement all impact the social entrepreneur and his success.

Mair and Noboa (2006) state that both individual and situational variables are important to determine intentions to behave entrepreneurially. Included in situational variables are social, economic and political factors present, often discussed in the context of precipitating or triggering events. Individual-based factors, which are the most prominent precursors of entrepreneurial intentions, include personality, background, dispositions, and proactiveness.

Mair and Noboa (2006) note that successful entrepreneurs rely on efficient networks. Entrepreneurs need social support, typically based on their social capital, a term commonly associated with trust, civic spirit, and solidarity.

\subsection{Implementation}

Haugh's (2007) model of non-profit venture creation includes six stages: 1) identifying opportunities; 2) articulating ideas; 3) owning ideas; 4) mobilising stakeholders; 5) exploiting opportunities; and 6) reporting to stakeholders.

Austin et al. (2006) highlight that the social entrepreneur needs to create a dynamic fit among four interrelated components: the people, the context, the deal, and the opportunity (PCDO).

Dees (2007) notes that today's social entrepreneurs are building on the tradition of Ben Franklin. The author proposes practical solutions that are contextualized. 


\subsubsection{Management}

Hockerts (2006) argues that a more upbeat interpretation of social entrepreneurship in non-profit organisations, is the notion that a good dose of market-orientation will help social organizations deliver more social value for the money they spend. Non-profit organisations can therefore be more efficient, and thus have a higher impact with a given budget, if they apply successful business practices (focus on the most effective programs, and use strategic planning and control mechanisms).

\subsubsection{Stakeholders}

Austin et al. (2006) state that to create motivation for joint action requires the creation of a common definition of opportunity that can be shared.

Dacin et al. (2011) note that The Big Issue - a street newspaper sold by the homeless and designed to allow them to earn a wage - provides an interesting example of the tensions that can emerge when a social venture seeks to achieve scale. The example illustrates how social entrepreneurs may find it difficult to achieve scale.

\subsubsection{Finance}

Boschee and McClurg (2003) argue that the rules of the game for non-profits have changed dramatically during the past 20 years. There has been a dramatic rise in operating costs, a decrease in resources available from traditional sources, a tripling of non-profits competing for grants and subsidies, and an escalation of the number of people in need. Smart non-profit managers and board members realize they need to be self-sufficient, which has led them naturally to the world of entrepreneurship.

Boschee and McClurg (2003) note that the non-profit sector has traditionally been driven by a "dependency" model, relying primarily on philanthropy, voluntarism and government subsidy, with earned income a distant fourth. However, this is no longer the case. Social entrepreneurs have moved from dependency to self-sufficiency.

Boschee and McClurg (2003) note that there lies an opportunity within every non-profit for earned income, and once a non-profit has successfully carried out a variety of earned income strategies, it may want to launch a formal business venture.

Hockerts (2006) states that the commercialisation of a non-profit organisation as a view of social entrepreneurship, brings a "for-profit" philosophy to the many non-profits that experienced a financial crunch in the 1980s, as they found it more and more difficult to finance their work through donations and grants. Some organisations have come up with strategies to generate income, by going at least partly "for profit," and many remain fearful of commercial operations undercutting their social mission. A viable business remains the best option to generate a dependable income to pay for charitable actions.

\subsubsection{Network}

Roberts and Woods (2005) note that Jeroo Billimoria, an Ashoka fellow, launched India's first 24-hour emergency telephone service, Childline, to assist police and provide healthcare for homeless children. When she approaches commercial organizations, she goes in asking for their expertise in exchange for hers, and does not ask for a cheque, as she considers that to be charity. The exchange creates the possibility of forming a partnership for long-term exchange.

\subsubsection{Organizational Form}

Townsend and Hart (2008) further examine the lack of consistency regarding the choice of organizational form of social entrepreneurship - for-profit and (versus) non-profit organisational forms - by looking at personal motivational goals, as well as the institutional environment. Mair and Marti (2006) state that social entrepreneurship can take place equally well on a not-for-profit basis, or on a for-profit basis. Their examination of various for-profit and not-for-profit initiatives suggests that the choice of set-up is typically dictated by the nature of the social needs addressed, the amount of resources needed, the scope for raising capital, and the ability to capture economic value.

\subsubsection{Context}

Short et al. (2009) point out that context also plays a key role in social entrepreneurship. Factors including tax, regulatory, socio-cultural, demographic, political, and macroeconomic factors, all have an impact on social entrepreneurship. Austin et al. (2006) explain that context is defined as those elements outside the control of the entrepreneur, that will influence success or failure.

Dees (2007) states that social entrepreneurship requires a supportive infrastructure, to help it develop 
further - it needs institutions to develop and make available to social entrepreneurs appropriate funding, talent, knowledge, and social capital. To help it flourish requires appropriate public policies, culture, and recognition.

\subsection{Conclusion}

There are certainly a number of distinct differences between ordinary entrepreneurship and social entrepreneurship. Social entrepreneurship looks at the world differently, and focuses on social value creation, social innovation, social opportunity, and has the potential to bring about social transformation and change, and economic development. Consequently, social entrepreneurs also view opportunity differently. Given their particular context, social entrepreneurs implement opportunities differently. With a specific focus on the perception and perspective of social entrepreneurs, a key question is the extent to which entrepreneurship can borrow from social entrepreneurship, and broaden its own perspective.

In light of this, the research addresses the following research question: how does social entrepreneurship and social entrepreneurial practice inform ordinary entrepreneurship and opportunity recognition? The following sub-questions are explored:

- What are the objectives of social entrepreneurship? How does social entrepreneurship thinking relate to entrepreneurship?

- How do social entrepreneurs identify opportunities and incorporate innovation? How does it relate to and compare with entrepreneurship? entrepreneurship?

How is social entrepreneurship implemented? How does it relate to and compare with

- What is the relationship between social entrepreneurship and entrepreneurship? How does social entrepreneurship contribute to entrepreneurship? How do social entrepreneurs perceive their competencies as ordinary entrepreneurs?

\section{Methodology}

In order to further study social entrepreneurship, and its relationship with entrepreneurship, semistructured interviews were carried out with experienced social entrepreneurs, and purposive sampling was used. Experienced social entrepreneurs would have developed a rich understanding of social entrepreneurship. 10 experienced social entrepreneurs were interviewed, all with at least 1 successful (operational, proven) social venture, and at least 3 years social entrepreneurship experience. Sampling was not constrained according to industry or type of venture, as the impact of this on the study was deemed negligible. Participants were identified through professional and business networks. Interviews on average lasted 1 hour. Interviews were recorded, transcribed, coded, and further analyzed.

\section{Results}

\subsection{What are the objectives of social entrepreneurship? How does social entrepreneurship thinking relate to entrepreneurship? \\ 4.1.1. Primary Objectives of Social Entrepreneurs}

The social entrepreneur wants to put people first. They have a heart for people and their needs. They have a social mission - they are interested in uplifting communities and bringing about social transformation and change. The social entrepreneur wants to empower people and make a positive impact on their lives. The social entrepreneur wants social impact to be competitive and visible, with a strong focus on sustainability. The social entrepreneur wants to respond to socio-economic circumstances and provide solutions. They want to act as an intermediary - as a catalyst and representative. Reaching people is just as important or more important to the social entrepreneur than making profit. The social entrepreneur is entrepreneurial, but within the integrated space of business/ profit and social mission. The social entrepreneur wants to break up the divide between purely for profit, and purely non-profit. Social entrepreneurship brings together the stakeholders and resources necessary for social impact.

\subsubsection{Social Entrepreneurship and Profitability}

Profit is not the social entrepreneur's primary objective. Making a change and impacting people's lives is just as important to the social entrepreneur. It's not that easy for the social entrepreneur to overlook and be insensitive to social errors or wrongs. People actually matter (a lot more) to the social entrepreneur. The social entrepreneur values social equity. 
The objective of the social entrepreneur is not primarily to make money, but to finance his social impact. The social entrepreneur sees a profit-only focus as not sustainable, both economically and socially. A purely profit perspective is a Western or outdated mindset, and not altogether and universally sustainable. The social entrepreneur does not altogether sacrifice profit, however, in that the social entrepreneur must guarantee sustainability. The social entrepreneur balances between social impact and sustainability. Social impact and social imperative over and above profit-making, increase the sustainability and attractiveness of the business. The social entrepreneur believes business, and social impact or mission, can be combined. Big corporations are also realising they have to bring about social impact and social change in their environments. Shareholders of big corporations are becoming more socially aware and socially conscious.

\subsubsection{Social Transformation}

Social entrepreneurship is all about social transformation. There cannot be social improvement or impact, without social transformation. The success of social entrepreneurship depends on, among other things, the people whose lives must be transformed, and their willingness and participation. People may not be ready for serious and considerable social transformation. In that case, the social entrepreneur can only wait. Furthermore, the system must also be ready for social transformation, such that successful social transformation does not have adverse effects, and can be absorbed by the system.

Social entrepreneurship has similar intentions than pure non-profit work, but social entrepreneurship is more sustainable than pure non-profit work, because it aims to be less reliant on grants and donations, and more self-sustainable with regards to funding.

Social entrepreneurs alone will likely not fix all the social ills. Social transformation is the role and duty of everyone. Everyone should contribute to living more sustainably, responsibly, and ethically. Still, social entrepreneurs have particular, additional, extra impact. They bring forth brilliant and innovative ideas and social enterprises to drive ideas. Social entrepreneurship can shape, direct and enrich social landscapes and contexts. Social entrepreneurship can increase healthy or positive activity and cooperation.

Social entrepreneurs are bridge builders. They play in and bridge the intersectional space of business and social mission. The social entrepreneur seeks to connect profit to passions or areas of interest. The social entrepreneur seeks to provide people with agency to support themselves. The business side of social entrepreneurship introduces the necessary formalities, structures and frameworks, while the social side of social entrepreneurship seeks to build a solution around the resources that are already present and existent.

Addressing social needs, can unlock opportunity. The way the social needs are addressed may be unconventional and innovative, but the primary focus is social in nature. Social change and transformation can be enabling in nature, and this allows unlocking potential, value and momentum. Social entrepreneurship can instigate social momentum, by focusing on empowerment. Social entrepreneurship acts as the catalyst to and for a number of opportunities. Social entrepreneurs can bring very unlikely opportunities together, and they can facilitate opportunity very well. Only social entrepreneurship can really unlock these opportunities, with everyone benefiting. In this sense, social entrepreneurship is transformative.

\subsubsection{Social Organization and Governance}

Social organization and governance are the responsibility of the people. Individuals are more efficient than government at looking after themselves. Individuals will enjoy a higher quality of life, if they look after themselves, rather than looking to government. The individual must be disciplined, structured, organized, and able to govern himself. Placing social responsibility on government creates nanny states, which causes problems. Every citizen should have social conscience. Government can encourage, nurture and support it, or hinder, crush, quell, and destroy it. Government can be a facilitator of, or hindrance to, social organization and governance. Government has a big role to play, but cannot manage by itself. Individuals should be far more socially responsible. They should be aware, informed, proactive, engaged and involved, and should take action more. Apathy has a big impact on individual participation. Government should create an enabling environment, rather than attempt to fix social problems and deficiencies on its own. Social entrepreneurs should not need to ask permission to participate and intervene in social ills. Social entrepreneurs should have greater freedom. This is when one would see true social innovation.

The traditional or old way of thinking was that social responsibility is that of government - government is responsible for social welfare. The role of the individual is far more important and relevant - his own values and cultural views. Government does not always and necessarily have the best in mind for the people they serve. Government may be self-serving. Government has a crucial, make-or-break social governance role. Government should evaluate and ensure that corporations have net positive social impact. Corporations can, and some do, see CSR and social impact as a competitive advantage, and part of their value proposition. 
Corporations understand that CSR and social impact can make business sense too.

\subsubsection{Social Entrepreneurship, Politics, and Economics}

Social entrepreneurship, and its intent and motivation, are broader than political or economic ideology. Social entrepreneurship is not about or motivated by politics, and does not necessarily subscribe to an economic ideology. Social entrepreneurship is more able to move and function outside of paradigms. Social entrepreneurship is able to jump between paradigms more, as it is a lot more inter-disciplinary. Social entrepreneurship is broader or more holistic in scope. Social entrepreneurship has greater freedom, and is less bound. It can combine profit and social impact. It can have/ achieve both profit and social impact.

Social entrepreneurship incorporates elements of politics and economics, or economic ideology. Social entrepreneurs are able to integrate different elements of various political and economic positions. Social entrepreneurship does not sacrifice financial wealth for social wealth, and vice versa. Social entrepreneurship may be more practical and pragmatic, and less ideological. Perhaps contrary to politics and economic orientation, social entrepreneurship has very simple premises and ideology: the social entrepreneur must be self-sustainable, and must focus on social impact.

\subsection{How do social entrepreneurs identify opportunities and incorporate innovation? How} does it relate to and compare with entrepreneurship?

\subsubsection{Identifying, Assessing and Evaluating Social Entrepreneurial Opportunities}

Social entrepreneurs may identify social entrepreneurial opportunities through social interactions interactions with people, visits to places, books, etc. They develop an eye for people's problems, and what people struggle with. They may focus on what they're are good at, and what they know well. It must be obvious that there is an opportunity. They may focus on uncontested areas. The social entrepreneur can easily identify social opportunities within his social context or environment, particularly if he is aware of his social context or environment. The social entrepreneur may look for other means or ways, and work on or around it, if his immediate idea is not suitable or practical. The social entrepreneur can identify social needs, based on personal needs. Needs can be converted into and reinterpreted as opportunities - finding a way to satisfy the need otherwise. The social entrepreneur can focus on the resources already available.

The passion and interests of the social entrepreneur play a big role in identifying social opportunities. The social entrepreneur may identify social needs and ills through his network, and in his context or environment. They may collaborate and partner with others. The social entrepreneur works to understand the social need or problem, to establish the need and extent of the need, the resources already available, and the possible solutions to the social need or ill. The social entrepreneur discusses the social problem and solution with the key stakeholders.

The social entrepreneur draws from his knowledge and experience. He focuses on his area of interest, and focuses on a particular aspect - finding the specific, specialist area where the social entrepreneur can add value. The social entrepreneur identifies a problem, finds a solution for it, or identifies an opportunity, and then takes it to the field to test it, and to refine it further, and continues from there. He builds awareness and reputation, seeks and builds up support, followers and momentum. The social entrepreneur looks for partners and collaborators, no matter what or how the other party contributes.

There is a process, and thought process, to judging and reviewing social project proposals. The social entrepreneur must verify that the social problem he has identified, is indeed a problem, and that it is worthwhile to address it: Whether the social problem is indeed recognized as a problem by those who experience it, and whether it is seen as a high priority problem to them. The social entrepreneur must be certain that he understands the social problem. The social entrepreneur must find a solution to the social problem. The social entrepreneur must check whether a solution to the social problem already exists. Can the social entrepreneur come up with a unique solution? How well did previous solutions fare? Can the social entrepreneur collaborate with others that already have a solution, or otherwise? The social entrepreneur must develop a business model around the social problem and solution - how is the social enterprise going to sustain itself? The social entrepreneur must consider implementation - how will the social entrepreneur implement on the ground?

\subsubsection{Social Movements, Social Health, and Social Entrepreneurial Opportunities}

There may be significant social ills or problems that accompany social movements and social trends, and this would point to social opportunities. The social movements and trends must be properly understood, to truly evaluate the existence and extent of the social opportunity. The social movements and trends can be researched, and discussed with experts and the social entrepreneur's network. There is a lot of shortsightedness with regards to focus. Also, there is a lot of reaction and shaming that is not necessarily indicative of trends. It 
therefore may be more beneficial, simpler, or quicker, to follow the work of experts. The social entrepreneur may pick up a lot of ideas, solutions, innovations and developments this way. The social entrepreneur can ride and latch on to social trends and movements, especially emerging social trends, to push and instigate social impact and change. It may also be more beneficial if the social entrepreneur specifically looks for, or researches, a specific issue or topic. Trends and knowledge on trends may take a while to research and develop. Societal issues are greater indicators of social opportunities for social entrepreneurs. It may also be difficult to get the full picture, because a lot may be hidden or obscure. It may not always be easy to interpret and follow the underlying social force. Not all social trends are pure or well grounded - based on true social need. Certain social forces may simply be concerning ideology, without true social need.

There are significant global social entrepreneurial trends. There is a strong setting of focus, awareness, and rallying, by global players such as universities, foundations and organizations, but it is mostly temporary and not sustained. Few countries, if any, are without social ills. It may simply be a matter of how evident or obscure the social ills are. There is not necessarily a direct relationship between social measures, and social health and wealth. Social indices may be high, yet social ills may still persist. It may simply be a case of, in countries with many social ills, it is easier to identify social opportunities.

\subsubsection{Differences between Social Entrepreneurial Opportunities}

Social opportunities differ in terms of context, environment, area, the solution required, and the support and resources available. How much perspective a social entrepreneur has on a particular social opportunity, differs. How aligned the social entrepreneur, and the network and resources of the social entrepreneur, are for different social opportunities, differs. The amount of passion a social entrepreneur has for different social opportunities, differs. The social entrepreneur focuses on and sticks to his fields of interest, and passions. His passions, interests, and experiences greatly impact the direction the social entrepreneur takes, and the opportunities he focuses on and identifies. Some opportunities are more difficult than others, because their social need is greater, or they require more fundamental social change or solutions.

Some social opportunities are more readily achievable than others. Some social opportunities may be very frustrating, because of their solutions, and the level of their solutions. They fundamentally require systems changes that may not be easily achievable, and that may require a lot of time and a long term perspective, even 15 years. The social entrepreneur may simply (want to) focus on simple solutions that can solve problems the simplest solution that can be easily implemented, that would be an answer to a social problem. It does not even have to involve innovation or technology, and it should be (is) easy to prove in terms of usefulness. The social entrepreneur may prefer social problems that require really simple, tangible, visible social solutions, that are also easy to prove and verify.

\subsubsection{Innovation}

Innovation is not necessarily a prerequisite for social entrepreneurship. It may simply be a case of better implementing existing solutions. A lot of the solutions that social entrepreneurs come up with, are rather common sense and straightforward.

Social entrepreneurship implies social change and improvement, and this can require innovation. Even if the social entrepreneur does not create or design a new product or invention, he must be creative and innovative in how he goes about it, so that he optimizes and maximizes his output. Social entrepreneurship entails a different way of thinking about social impact and change, and therefore requires innovation. The social entrepreneur involves innovation in the way he tackles social problems, etc. The social entrepreneur therefore needs to be innovative and creative in the way he brings together stakeholders and implement interventions. The social entrepreneur cannot simply address the surface problem or ill, but needs to suggest and propose sustainable and effective solutions that address the problem fundamentally and systematically, and this may require a lot of innovation.

Even social entrepreneurs run the risk of being put out of business because of complacency. There is generally more than one solution or idea to a problem. The social entrepreneur may innovate around his idea or solution, and develop it further, to increase the value offering. This may involve bringing others on board, and looking for collaboration and synergy. To that end, the reputation of the social entrepreneur can open doors for him. Innovation may not be enough, however. It must be radical or disruptive in nature, to be able to truly contribute to social transformation, and thus social entrepreneurship or social impact. It must be able to, and allow the system to be changed and transformed.

\subsubsection{Reactive versus Proactive Social Entrepreneurship}

Most social entrepreneurs are reactive, in that they do not go and look for social problems to work on. 
Rather, they cross paths with the social problem, and this makes them pay attention to the social problem. In most cases, the focus of the social entrepreneur's life is changed by a reaction to an event or condition the social entrepreneur experiences or becomes aware of, and that upsets or angers the social entrepreneur. More proactive social entrepreneurs would educate, train and skill themselves, direct their lives towards social entrepreneurship, and look for social opportunities. Social entrepreneurship can be proactive in the sense of increased awareness of social environments and contexts, and increased desire to bring about social impact. In some industries or sectors, it is becoming a movement, philosophy, lifestyle, and belief system. The social entrepreneur may be very creative and innovative, and this may imply that the social entrepreneur can be more transformative than reactive. Social entrepreneurship must be proactive to have really sustainable and impactful solutions.

Pure non-profit work is considered a lot more reactionary work. Social entrepreneurship targets sustained social impact or social change. Social entrepreneurship is more holistic in thinking, and aims to revise, redesign and restructure the whole system, to correct the social deficiency at the roots, and in a sustainable manner. Social entrepreneurship seeks to close social gaps, but in a sustainable way. This can be seen as realigning the entire system. Social entrepreneurship may not simply address the immediate social need or deficiency, but would aim to address it more holistically and at a broader or more fundamental level, and in a sustainable way.

Money and power are two of the factors that determine how proactive social entrepreneurship can be. For certain social interventions, the social entrepreneur may need a substantial amount of money and/ or power, particularly if the social entrepreneur must go against the system or norm for truly successful intervention. Current norms, tradition, and culture may prevent social entrepreneurship, and proactive or transformational social entrepreneurship. In such cases, the social entrepreneur can only wait for a gap, and hope for an internal change or shock. Current worldviews and expectations determine how social entrepreneurship, and the relevance of social entrepreneurship and social change, are seen.

A number of factors prohibit social entrepreneurship from being proactive, and thus prohibits social transformation. Municipalities, etc., are assigned responsibility, but are rendered ineffective through legislation and compliance. Their processes make them inefficient and ineffective. NGOs have the right heart, but compete with each other, are ineffective, and lack innovation/ innovativeness. Different social entrepreneurial stakeholders also in conflict, and step on each others' toes in terms of their missions and objectives. Social opportunities can be radical in nature and bring about social transformation.

\subsubsection{Disruptive Social Entrepreneurship}

Social entrepreneurs can be very innovative and creative, and this can enable social entrepreneurship to be disruptive or radical at times - to have significant or groundbreaking social impact. Very creative and innovative social entrepreneurs like to challenge and break with the status quo and systems. Social entrepreneurship, and the social change resulting from it, must be radical and disruptive, instead of common, to really have a significant social impact. To be truly effective, the main task of social entrepreneurship should be to be disruptive - to effectively change the system. Otherwise, social entrepreneurship is simply treating or alleviating symptoms. The amount of social impact the social entrepreneur will have, depends on how disruptive or radical he and his solutions are. More and more people are coming together and collaborating to bring about social improvement.

Social entrepreneurship can disrupt the mindset of businesses - how businesses think. Social entrepreneurship (can) cause businesses to be more aware of social contexts and social environments, particularly those of its customers, and to be more conscious of their social image - to be seen as socially responsible. All of this can lead to positive spin-offs. Social entrepreneurs introduce products for applications where commercial products don't work, and where existing solutions don't work. Businesses are increasingly becoming aware of the value of social innovation, social impact and social good, and for these reasons, will regard social entrepreneurship and social entrepreneurs. In this sense, social entrepreneurship can be innovative and thus disruptive. Social entrepreneurship can expand and broaden perspective. Social entrepreneurship is less disruptive in the sense of commercial products.

\subsubsection{Radical Social Entrepreneurship}

There is a place or need for radical social entrepreneurship, although society may not always be ready for it. A lot of social entrepreneurs fail, because they don't get the support they need. Awareness and experience of, and exposure to, social entrepreneurship are limited. People either want to hear about profit, or social impact, and are unable to connect or combine the two. People still measure outcomes, rather than impact. Many are not willing to address or contribute to social impact, or social ills, without monetary gain. Unrealistic 
government support programs, where prerequisites are unrealistic, limit the ability to unlock potential and action. Legislation and corruption can also hinder radical, or more radical, social entrepreneurship.

The innovation that comes with, or that is embedded in, a social opportunity or enterprise may be radical. Radical social entrepreneurship is more likely, the greater the social need, and the greater the imperative or objective to bring about social impact. The more radical the social entrepreneur, the more likely his chances of surviving. The more passionate the social entrepreneur, the more radical he is likely to be.

Radical social entrepreneurship can be explicit - shocking to instigate thought, awareness and change. Radical social entrepreneurship can be pervasive - using each and every possible channel to promote social impact and change. Radical social entrepreneurship reduces barriers to access and participation. Radical social entrepreneurship is smart, clever, and innovative. It uses new and clever ways, including technology, to promote social impact and change.

\subsubsection{Developing Solutions for Social Problems}

The social entrepreneur may come up with solutions to social problems through a lot of conversations, also about possibility. They may learn from other contexts and experiences, build on past solutions and further advance them, increase exposure and experiences, and may rely a lot on intuition to obtain ideas.

Understanding the social problem and its context, is one of the most important things the social entrepreneur must do. The social entrepreneur fully immerses himself in the social context or environment of the social problem he wishes to address. The social entrepreneur must get to know the people that are to benefit from his social intervention and work. This involves the economic, geographical, gender context, etc. The social entrepreneur must know as much as possible about the problem he wishes to address, its context, and the people that experience the problem. Most successful social entrepreneurs are deeply and personally engaged in the work they are doing. The social entrepreneur cannot see the problem as one among many, and must spend time to understand the context. It is not enough to come up with an idea. The social entrepreneur must engage the context to make the idea work.

Solutions entail how social entrepreneurs design interventions. The social entrepreneur uses problem solving skills. The social entrepreneur applies theoretical frameworks and perspective, to think about problems and their solutions. The social entrepreneur defines the social challenge or problem he wishes to address and solve. The social entrepreneur thinks of potential solutions to the social problem or issue addressed. The social entrepreneur looks for partners he can involve, including partners to help with funding and implementation. The social entrepreneur designs a project plan and assigns roles. The social entrepreneur applies a lot of project management skill.

The social entrepreneur may build on his passion and interests. The social entrepreneur observes, and identifies issues and problems within his field of interest. The social entrepreneur then resolves to change, impact, or solve the matter. The social entrepreneur thinks of a solution to the identified issue or problem, and further thinks of additional, new, and better ways to solve the problem or issue. The social entrepreneur learns, develops, acquires, etc, what is necessary to solve the issue or problem.

\subsection{How is social entrepreneurship implemented? How does it relate to and compare with entrepreneurship?}

Implementation of social entrepreneurship can be considered and approached from both a micro level, and a macro level. In general, the former refers to implementation by the social entrepreneur, whilst the latter refers to (the sophistication of) social entrepreneurship practice within a nation, etc.

\section{Micro-level}

\subsubsection{Entrepreneurship and Business Experience}

Entrepreneurship- and business-experience are essential to the social entrepreneur. The social entrepreneur can be too focused on the social change he wants to make, and may focus too little on the financial side and implications - how to fund the social impact. Business experience helps restore focus, and helps to consider the financial side as well. It helps the social entrepreneur to be financially sustainable. The social entrepreneur needs more than just a good idea. The social entrepreneur may need more than just heart. Social entrepreneurship requires a lot of hard work, energy and drive. An entrepreneurial and business background enables and prepares the social entrepreneur so much more. It helps the social entrepreneur to understand systems, how to navigate problems and complexity, how to work with people and bring out the best in people, and build relationships. A social project or venture may take a long time. The social entrepreneur must seek support for his social project or venture. The social entrepreneur must find the people who will help him realize his social project or venture. People who get lucky, are people who are funded well, have great networks, and 
are well supported. In most cases the social entrepreneur has to work his way up.

Many social entrepreneurs start off with very little experience, particularly of running an organization. They focus more on addressing a social problem they have identified. Social enterprises do not really differ from normal businesses, particularly in terms of the activities and skills involved. The social entrepreneur must still be able to sell his idea, get people interested in the idea, get customers, benefactors and partners, work with people and manage staff, do marketing, and manage the financials. The social enterprise is still much run like a business, and social entrepreneurs benefit from business experience.

Some social entrepreneurs start as entrepreneurs. The social entrepreneur should know how to run a business, and apply business principles, skills and thinking to social entrepreneurship - it impacts his success. Most social entrepreneurs know and apply entrepreneurship and business thinking. The social entrepreneur must be sustainable, and for this he needs entrepreneurship and business thinking and skills, etc.

\subsubsection{Achieving Sustainability and Self-Sufficiency}

To be able to call yourself a social entrepreneur, your ideas must be sustainable, and must be able to pay for themselves. The social entrepreneur that is self-funded to a large extent, or that is reliant on grants or donations, is less likely to become self-sufficient. Self-sufficiency should be part of the mindset of the social entrepreneur. The social entrepreneur needs to come up with and have a meaningful or valued product or service offering. Entrepreneurial skills, knowledge and thinking come in handy here.

The ability of the social entrepreneur to be sustainable, depends on the extent that the social entrepreneur services and satisfies a particular social need, how well the social entrepreneur can measure his social impact, and how well the social entrepreneur can look for funding, other than grants or donations. Positive social impact is likely to lead to sustainability - the social venture is able to sustain itself and even expand. The social entrepreneur needs to both have positive social impact, and to recuperate cost, to be sustainable. At some point, one expects the social venture to be able to cover its costs, as part of sustainability.

Some of the work or impact of social entrepreneurs are very quantifiable and beneficial, such that the social entrepreneur may be able to attract financial support or remuneration for this. The social entrepreneur may consider this avenue. A lot of social entrepreneurship work may also be connected to guarantees guaranteeing certain outcomes. This too can attract financial support or remuneration. Many social entrepreneurs and related entities, like not-for-profits, do the work government should be doing. It is thus not unrealistic to expect government to support social entrepreneurs. Government's efficiency has a big impact on the amount of social work necessary. Government may also become complacent, due to the presence of social entrepreneurs and non-profits, who really do their work for them. A great deal of research and development goes into social entrepreneurship as well. The angel investment space can be developed for social entrepreneurship. Angels can provide seed capital for social entrepreneurs. It will provide the social entrepreneur some leeway. Social entrepreneurs can then focus on being innovative. Financial support will allow social entrepreneurs to be more innovative. Social entrepreneurs frequently fail when they attempt to scale, and can't secure funding or finance to scale. Social entrepreneurs and enterprises may develop differently than conventional enterprises. They may take as much investment as entrepreneurs. Social entrepreneurs also have (unique) structural needs - moving social enterprises through their stages.

There is a lot to come from social entrepreneurship still. Social entrepreneurship has the potential to be far more sustainable in the future. There is plenty of social opportunity to make social entrepreneurship sustainable. If the social entrepreneur is very calculated and organized, and has good financial management, he is far more likely to be financially sustainable sooner. The social entrepreneur should not focus solely on social impact, but must also consider financial sustainability.

It may take some time for the social entrepreneur to become self-sustainable. A lot of things can impact the self-sustainability of the social entrepreneur, e.g. the leadership of the social enterprise. The founder may start to stifle growth. The social enterprise must continue to innovate, to be able to continue being sustainable. To be successful, the social entrepreneur must understand both the business side, and the social side - how to devise and implement social solutions, and how to manage and maintain the business or financial side. Skills development and training are also important: the people involved in and employed by the social enterprise, and their skills. The social entrepreneur must implement and adhere to strict financial controls, and must run the social venture along strict business lines. The social entrepreneur must have and operate on strategy and plan, rather than feeling. The social entrepreneur should be conscious of, and deliberate about, financial sustainability. Collaboration helps sustainability and self-sufficiency. The social entrepreneur needs accountability, constructive feedback, and criticism, also on his direction, plans and ideas. The social entrepreneur can focus on social needs that are high in demand, and that are less seasonal. 


\subsubsection{Getting a Social Enterprise off the Ground}

It takes patience to get a social enterprise off the ground. The social entrepreneur needs to prove his idea and concept first. He must verify that his opportunity has merit, value, and demand. What the social entrepreneur does, must be useful, people must be willing to support it, and it must solve an existing problem. The social entrepreneur must first test his idea. The social entrepreneur must find the people that will help him realize the idea, and that supports his vision. Too many social entrepreneurs create a social enterprise, before they have verified that what they are doing is helpful. It may take a while to verify and clarify that the social entrepreneur is doing something useful. It helps if the social entrepreneur starts small - it is not uncommon for the social entrepreneur to start with little or nothing. The social entrepreneur may first do something else that can generate funds and that can help to sustain his social venture. The social entrepreneur may grow his social venture very organically. The social entrepreneur can get off the ground, simply by being innovative enough.

The social entrepreneur needs to talk about his social opportunity and venture. The social entrepreneur can log his ideas and thoughts, which can be helpful. Reading a lot helps the social entrepreneur to build multiple perspectives. The social entrepreneur needs to think about his social opportunity and venture realistically. The social entrepreneur can build momentum around his social opportunity and venture, and can look for partners or collaborators that he can work with, who align with his social mission, or who he aligns with in terms of social mission.

Starting a social enterprise is similar to starting an entrepreneurial business or venture. It requires generating a business model, and answering key questions regarding the social venture - its product, resources, funding model, and value proposition. It involves asking a lot of the same questions an entrepreneur would ask. The social entrepreneur needs to be realistic about and cognizant of the time it will take. There are the practicalities, regulations, and processes the social entrepreneur must comply with and get in place. The social entrepreneur must follow proper procedure, and work within the system. The social entrepreneur should get going, so that he can build on his work, and refine and develop it. It helps if the social entrepreneur is innovative when it comes to securing finances for his social opportunity or venture, and if he can work with the finances innovatively - securing the finances in creative ways and stretching it through creative ways.

\subsubsection{Measuring Social Value and Impact}

One of the struggles of social entrepreneurship is to quantify and measure social value or impact. It may be difficult and expensive to know the real or true impact the social entrepreneur has, and the social entrepreneur may not have resources for this. Social entrepreneurs may make use of anecdotal evidence. The social entrepreneur may have an impact at different levels. It may be difficult to robustly measure the impact the social entrepreneur has. A lot of the social entrepreneur's work may have indirect impact, or positive externalities. It may not be realized or be evident immediately. It may not be clear how long or how far the social entrepreneur's work carries and has impact.

Social entrepreneurs assess risk very well, they just do it differently. The value the social entrepreneur brings is measured in terms of things such as their ability to bring together (their) passion, process, possibility, people and ideas, and the social entrepreneur's dissatisfaction with systems that do not work. The impact of the social entrepreneur is measured by the impact the social entrepreneur had on the people that benefited from the work of the social entrepreneur. This can be achieved by collecting feedback on results and progress. Social entrepreneurship has a social multiplier effect. The measure of social impact should be created before the social project starts, and should be customized to, and unique for, each project. It must be an impact measurement, and not a power measurement. It is an impact measure, and thus contrary to performance measures government typically use. The impact measurement entails a social return on investment measurement. Because social entrepreneurship work is not that easy to quantify, it is easily and generally under-estimated. It is not always easy to quantify the impact a social entrepreneur can have, or has, on a person's life. A key measure of social entrepreneurship work or impact may be enablement of people's individual agency - the extent by which they grew more self-sustaining, and independent or self-dependent, and are able to help themselves and improve their own lives.

Social entrepreneurs need to be attentive and sensitive to their monitoring and evaluation: Constantly refining, re-evaluating, and redefining what the social impact is, as well as keeping close contact with beneficiaries - those you are helping - and questioning and evaluating your impact. Beneficiaries determine/ indicate/ reflect how much impact the social entrepreneur has. Social entrepreneurship requires very strict, objective, truthful, honest, uncompromising, and factual, to-the-point monitoring and evaluation of impact. This is actually attractive to (external) stakeholders, like investors.

It may be difficult to measure social impact, or social entrepreneurial impact. Social impact may be more indirectly observable, than directly observable. Social entrepreneurship may not have a fixed outcome - 
the social impact may not be guaranteed, particularly because it involves impacting people's lives. Social enterprises may take longer than traditional enterprises to show profit or results. Social entrepreneurship may be viewed as riskier, or more uncertain, than entrepreneurship. Social entrepreneurship may require a lot more patience than entrepreneurship, and patience may be in short supply.

\subsubsection{Network}

His network is very important to the social entrepreneur. The social entrepreneur has diverse networks that comprise all relevant levels - from the small guy to the big guy. His networks also involve diverse stakeholders - friendships, businesses, churches, NGOs, and civic organizations. The social entrepreneur may source or improve social opportunities through his network. The social entrepreneur can learn and gain exposure and experience from/ through his network. His network helps the social entrepreneur to develop and advance opportunities and ideas further. The social entrepreneur may find true support and feedback with and through his network. His network extends the expertise of the social entrepreneur. He can draw on experts outside his own area of expertise. The social entrepreneur can gain access to resources through his network, including funding. His network increases the chances for the social entrepreneur to collaborate, to partner, and to connect. The reputation of the social entrepreneur, particularly in his specific sector, is also very important. The depth of relationship the social entrepreneur has with his network is also key. Building strong relationships, not for immediate benefits, but with long term perspective, and also with higher order benefits in mind, is important to the social entrepreneur.

\subsubsection{Organizational Type}

The setup of the social enterprise depends much on the structure, nature and purpose of the social enterprise - the type of funding the social enterprise plans to use. A functioning network or collaboration of social entrepreneurs may be the best, but may not always be practical from a financial and funding perspective. The motive of the social entrepreneurial organization has to be managed. There is both a power and profit motive or aspect to social entrepreneurship, which has to be managed and integrated appropriately. Those looking for money must (be able to) earn it. Those looking for influence must assume responsibility. Influence and responsibility are assigned accordingly. To that end, the social entrepreneur can structure a NGO to work alongside a for-profit, and to be contained within a for-profit.

There are too much red tape and bureaucracy around non-profits, and a non-profit setup, that severely restrict this option. Support from corporations is also lacking. Self-sufficiency provides a lot more freedom to the social entrepreneur, and is likely to come through a for-profit setup. On the other hand, a non-profit setup allows the social entrepreneur to apply for funding, and to partner with corporations. A non-profit setup makes it very clear that the social entrepreneur is not after profit. A for-profit doing non-profit or social work, has the potential disadvantage of a double image.

A hybrid setup is a good setup for social entrepreneurs. The structure is also tactical, and depends on the predominant origin of funds. Certain income streams would require a non-profit entity, to have the right legal vehicle. A more profit-based financing would require a company setup of some sort. Operating a social venture partly or fully for profit, increases financial accountability, and awareness of sustainability. Profit can still be invested and reinvested in social causes. The social entrepreneur can simply be very clear that he is also conscious of sustainability. The social entrepreneur cannot call himself a true social entrepreneur, if he is not self-sustainable. There are (support) structures to set up a non-profit, which may be a useful vehicle, however, the social entrepreneur should be conscious of financial sustainability, and should not depend or rely on grants and donations.

\subsubsection{Opposition and resistance}

Social entrepreneurs generally get along easily, and cooperate with less - hardly any - competition. Social entrepreneurs are less competitive than entrepreneurs - they do not necessarily directly compete so much, but are far more willing to collaborate, partner, and work together. Social entrepreneurs far more build on each others' work. Social entrepreneurs and social entrepreneurship can become lonely, and there are benefits to collaboration and networking with like-minded people. It is easier for social entrepreneurs to establish and define common ground and goals. The reputation of the social entrepreneur may help and benefit him a lot, and may open a lot of doors for him. Social entrepreneurs are normally of good character and integrity, and are generally more moral and ethical. Because of what they do, and their dedication, social entrepreneurs are admirable people.

The social entrepreneur may face opposition from current systems and their owners, like government. Social entrepreneurs face a number of challenges: they can get burned, their ideas get stolen, and they are 
under-funded. Social entrepreneurs are under-appreciated in light of their level of contribution. There may be competition between social entrepreneurs with very similar offerings in the same area. The social entrepreneurs may compete for reputation. Social entrepreneurs and their names or reputations, may get used and exploited by shenanigans and fraudsters within social entrepreneurship. This can cause them to withdraw, close up, and lose trust. Social entrepreneurs - or social entrepreneurship - would need to perform better screening, to circumvent and avoid fraud. The social entrepreneur can get used and misused. The social entrepreneur may face disrespect, opposition, resistance and critique, and may be treated poorly. The social entrepreneur relies on his support system to recover and recuperate, to persist and persevere. Because heart is also involved, social entrepreneurs may get very defensive about, over-protective of, and attached to, their ideas. Social entrepreneurs may get stuck in this way, so that they lose perspective and struggle to move forward.

\section{Macro-level}

\subsubsection{The Role of Corporations and Government}

Government and social entrepreneurs differ considerably, and do not think the same. This makes cooperation and collaboration between government and social entrepreneurship difficult. The philosophy, and approach to social work and intervention, of government and social entrepreneurship differ substantially. There is a lot government must do to improve its relationship with social entrepreneurship. A lot of maturity is also required on the side of government. Both government and corporations can contribute more to social entrepreneurship. Government and corporations are enablers of social entrepreneurship, particularly through funding. Government should rather create a conducive environment for social entrepreneurship, than operate in the social entrepreneurship environment. Bureaucracy stifles entrepreneurship and social entrepreneurship. Corporations have a certain culture, tradition and modus operandi, and find it difficult to work with the dual mission of social entrepreneurship. Corporations can constrain social entrepreneurship too, through their requirements on, and measures of, social entrepreneurship. Government and corporations may be slow when it comes to decision making around social entrepreneurship, and this can adversely affect social entrepreneurship. To be successful, social entrepreneurship requires a lot of support, participation and collaboration from government, corporations and society, without government or corporations necessarily operating in the area themselves.

Government has a huge influence over education. Government can better use education to train youth to be problem solvers, team players, and to have empathy. Government can thus train youth to be social entrepreneurs from an early age. Government can cultivate creativity and innovation through education. However, government is more interested in entrepreneurship than social entrepreneurship. Government looks to entrepreneurship to build economies and businesses, and to generate income, and undervalues social entrepreneurship.

Government poorly understands social entrepreneurship. Government would rather push social entrepreneurship onto the private sector, and develop it that way. Government and corporations are still struggling to figure out where social entrepreneurship fits in, and how to use and fund social entrepreneurship. Corporations already have their hands full with enterprise development and other social work around/ for compliance. Government and corporations are struggling to understand how the interaction with social entrepreneurship will work - the contribution of social entrepreneurship, and in turn the needs of social entrepreneurship.

Government may be inefficient, ineffective, and wasteful, when it comes to addressing social needs and bringing about social impact. Government is also poor at choosing social projects to fund. It is not easy to measure social impact, and this aggravates it. Reporting on social entrepreneurship is challenging and not straightforward. Government and other beneficiaries prefer concrete measures, or measurements that are easy to manage and that are not ambiguous. Further, the outcome of the social project may not be fully under the control of the social entrepreneur, and may just as much depend on the other stakeholders, like the project participants.

Certain corporations have funding available, and are happy with a more detached approach to partnering with social entrepreneurs. They merely wish to achieve their social responsibilities. Corporations realize that their spending on CSI is mandatory. They wish to maximize impact on/ for their business, claim any incentives like tax rebates, etc, and minimize the cost. Corporations should increase their collaboration with social entrepreneurs, because social entrepreneurs can be very creative and innovative with regards to problem solving. Corporations are seen to focus on higher LSMs (that they believe are economically and commercially viable). This may essentially be immoral, and may overlook opportunity. Corporations underestimate the complexity of social needs and social needs communities - the communities and environments in which the social need resides. Corporations require a change in attitude, particularly their 
paternalistic attitude.

\subsubsection{Social Entrepreneurial Opportunities in Organizations and Institutions}

Wherever there are social problems or ills, there are social opportunities. There may be social opportunities in places or areas such as corporations, to the extent that there are social problems or ills. There are a number of constraints within organizations, however. The entrepreneur's or social entrepreneur's innovation is constrained in organizations. Even organizations one would expect to be entrepreneurial and innovative, or conducive in this regard, like universities, may be constrained and constraining. Social entrepreneurs must look for opportunities, even if the environment is not necessarily conducive to social entrepreneurship. The true social entrepreneur will keep trying.

Support for social entrepreneurs from corporations is limited. However, awareness and acceptance of social entrepreneurship is increasing. The awareness of social entrepreneurs is also increasing - educating social entrepreneurs, also on what to expect, and how to respond. Corporations are more willing to collaborate, partner and work with social entrepreneurs, if they realize the social entrepreneur has something to offer, or has a solution they don't have. Corporations are also increasing their social entrepreneurial resources, capabilities, capacity, etc, by incorporating social entrepreneurship and partnering with social entrepreneurs. A lot of what corporations do can also be described as social entrepreneurship. Corporations can contribute to social entrepreneurship, by being funding and implementation partners.

Corporate culture can both be a hindrance to and enabler of social entrepreneurship. Culture influences what the social entrepreneur can and should address. Culture can impact barriers to engaging in social entrepreneurship or social work, and social opportunities. Culture also impacts and defines the social environment and context. Government and organizations can create an environment conducive to social entrepreneurship and social innovation, create awareness around social entrepreneurship and social innovation, educate and train for social entrepreneurship and social innovation, and incentivize social entrepreneurship and social innovation.

\subsubsection{Factors hindering social entrepreneurship and its development}

Government may in fact be a hindrance to social entrepreneurship, as well as be guilty of corruption and abuse of resources and power. Government support comes with a lot of requirements, prerequisites and red tape. Government poorly evaluates social entrepreneurial ventures. Government policy and competence are lacking when it comes to social entrepreneurship. Government is not committed to social entrepreneurship - government does not go the extra mile when it comes to social entrepreneurship. Informal leadership within a community can also be a hindrance.

Finance may be a big hindrance to social entrepreneurship. This points to a bigger issue - the lack of government and corporate involvement, support and partnership, and lack of social entrepreneurship development and training. Social entrepreneurship lacks access to funding opportunities to support the social entrepreneur while he works to become sustainable. Issues around financial setup may be a hindrance to the social entrepreneur. The social entrepreneur setting up as a for-profit has distinct benefits, but it simultaneously limits the social entrepreneur in terms of sponsorship and partnership.

Social entrepreneurs are not given a fair chance. There is little faith in social entrepreneurs, and an unwillingness to wait for the social project to bear fruit. There may be a lack of support and buy in for the social project, and seeing the social vision. There may be negative connotations, associations, and conceptions tied to social entrepreneurship. There is stereotypical thinking surrounding social entrepreneurship. The social entrepreneur is seen as a charity that requires funding to survive, and that provides little value. There is a lack of social entrepreneurship awareness and education.

The sheer volume of social ills and social problems creates demand for social entrepreneurship. The social climate is such that it is likely adding to, and aggravating social problems and ills. The social problems may be too vast, for social entrepreneurs to truly make a difference. A conducive environment for social entrepreneurship still needs to be developed. The economy is not as vibrant as it needs to be, so social entrepreneurship needs support. Social entrepreneurship and certain social entrepreneurs may still suffer prejudice. Such social entrepreneurs require additional support.

\subsubsection{Developments in Social Entrepreneurship}

Awareness of, and interest in social entrepreneurship are growing. This helps the development of social entrepreneurship. There is an increase in work aimed at supporting and funding social entrepreneurship, e.g. angel investment, venture capital, and impact funding. There is a move from merely a focus on social impact - doing good - to sustainable social impact - doing good, whilst being self-sustaining. Social entrepreneurship 
vehicles have developed, like hybrid models (marrying the business side and the social impact side). There are developments in technology and the use of technology, digitization, and decentralization (moving away from dependency on the state). Technology is expanding in poor communities, and again flowing back to urban areas - social entrepreneurship is at the helm of this.

There has been an increase in social entrepreneurship due to unemployment. Drivers in this regard are poverty, crime, or simply a lack of jobs. Economic conditions and the environment have had a great impact on social entrepreneurship. Government and corporations are (becoming) more interested in social entrepreneurship. Regulation, like BEE and BEE scores, are contributing to this. A partnership with a nonprofit makes things a lot easier for corporations. Corporations are therefore making a contribution socially. Women entrepreneurs are rising and finding support. Public benefit processes that can be extended or expanded to social enterprises or social causes, are rising. There are a lot of opportunities for social entrepreneurs in certain industries, like hospitality and tourism. Collaboration, training and support for social entrepreneurs are rising, even among social entrepreneurs themselves, albeit at a slow pace.

\subsubsection{Government Support of Social Entrepreneurship}

Government must have a social agenda and program. It must have effective, sustainable, constructive and productive social objectives. Government must channel and implement social entrepreneurs along and according to its social objectives. Government can assist social entrepreneurs with funding, and can increase funding to social entrepreneurs. It can provide more participatory, active or dynamic funding - enough to ensure the social entrepreneur can continue; enough for each period (month, etc), according to their need and performance, and to get them off the ground. It should be more funding that is linked to support, and not merely funding for the sake of being able to say funding was provided. Social entrepreneurs require support for at least five years, as it can take the social entrepreneur that long to succeed. There should be programs with this objective. Government can help social entrepreneurs with structuring their social enterprises, and make structuring of social enterprises easier.

Government can develop social entrepreneurship policy, and increase the effectiveness of social entrepreneurship policy. Government can improve its implementation of its programs targeted at social entrepreneurs. Government should increase measures to protect and secure credibility in the social entrepreneurship sector, through proper track record checks, etc. Government can improve the social landscape, by improving the education system, to create better citizens. Government should change and improve its leadership, also of social entrepreneurship. Leadership should be more empathetic, more socially conscious and aware, less self-serving, and more concerned about the greater good. Government should engage, regard, involve and communicate with social entrepreneurs more. Government can collaborate with social entrepreneurs more, and allow social entrepreneurship a bigger stake and role. Government should facilitate social entrepreneurship, create an environment for social entrepreneurship, and step back and allow social entrepreneurship space and room to operate. It can accelerate government (public) private partnerships (PPP), or outsource to social entrepreneurs. Government can channel social entrepreneurs for and towards development, like economic development. Government can reduce red tape and bureaucracy around social entrepreneurship. Government can collaborate and share resources with social entrepreneurship more. It should not politicize social entrepreneurship. Corruption is impacting and reducing the effectiveness of social entrepreneurship, and government social entrepreneurship programs.

4.4. What is the relationship between social entrepreneurship and entrepreneurship? How does social entrepreneurship contribute to entrepreneurship? How do social entrepreneurs perceive their competencies as ordinary entrepreneurs?

\subsubsection{Comparing Social Entrepreneurship and Entrepreneurship}

Focus: Entrepreneurs primarily focus on and regard profit - profit enjoys high priority, and it is one of the things that are considered first. Social entrepreneurs primarily focus on and regard social impact - social impact enjoys high priority, and it is one of the things that are considered first. The social entrepreneur may have to sacrifice profit to achieve a social impact objective, and social entrepreneurship may come with this opportunity cost.

Dual mission: Social entrepreneurship may be more difficult than entrepreneurship, because it is straddling two objectives - it must find a way to be financially sustainable, to be able to bring about and fund/ sustain its social impact.

Type of need: Social entrepreneurship may also target a different class of need - entrepreneurship generally targets needs people are willing to pay for, whilst social entrepreneurship targets needs people are unable to pay for, or not necessarily willing, or less willing, to pay for. 
Sustainability: Financial sustainability is generally a far greater concern for the social entrepreneur, than the entrepreneur. Social entrepreneurship may be more difficult to sustain financially. Social entrepreneurship is not necessarily targeted at formal markets and formal customers - it does not necessarily have formal markets and formal clients that can pay. It is not so much coming up with solutions, or being innovative, but concurrently generating some form of income to sustain the venture.

Innovation and problem solving: Social entrepreneurship is similar to entrepreneurship in that the entrepreneur or social entrepreneur will find a solution for whatever problem he faces. Their avenues may differ, but the nature or mind of the social entrepreneur and entrepreneur is much the same. Both solve problems and provide solutions, and run businesses.

Risk: Whether social entrepreneurship is riskier than entrepreneurship depends on industry and context. Both social entrepreneurship and entrepreneurship are risky. Both social entrepreneurship and entrepreneurship put pressure and stress on the social entrepreneur/ entrepreneur. Markets are generally competitive, making entrepreneurship risky. The entrepreneur may be pressed to be competitive, and turn a profit.

Social entrepreneurs also face unique challenges. Social entrepreneurship can be riskier than entrepreneurship, because it involves people and impacting people - having social impact - and this makes it more difficult and uncertain. The duel objective of social entrepreneurship makes social entrepreneurship riskier than entrepreneurship. Stakeholders are predominantly profit driven, and it is hard to get buy in for the social entrepreneurial concept or venture.

With social entrepreneurship, actual results may take longer to achieve, and there may be little or no results or progress evident for a considerable time. Particularly, or more so, in social entrepreneurship, the effort put in does not necessarily translate to outcome. With social entrepreneurship, there are a lot more external factors that determine the outcome and results of the social venture.

Business concept and model: Social entrepreneurship may be harder than entrepreneurship, in that the social entrepreneur has to build a business model around a social problem he wishes to address. He has to ensure that a social problem can be, and is, addressed in a sustainable way. In many cases, the social ill or problem may be a dead cost, with little direct opportunity for a business model and sustainability. Entrepreneurs do not have a dual, often contradicting objective; they have clear markets, and much more clear, direct and simple business models. Just as the entrepreneur, the social entrepreneur creates value, but with social entrepreneurship, capturing value created is not direct as with entrepreneurship, and the social entrepreneur must introduce a third leg to the process and the value flow.

Startup: Both entrepreneurs and social entrepreneurs may find it difficult to get off the ground, and become successful. An entrepreneurship startup is more difficult than a social entrepreneurship startup. Entrepreneurship takes greater planning, research and upfront investment.

Finance, funding: Financial resources may be more difficult to obtain and sustain with social entrepreneurship. The reputation of the social entrepreneur also plays a role. The social entrepreneur with a reputation may find it a lot easier to get support.

Competition, barriers, capital requirements: The scale at which the social entrepreneur engages, also determines how difficult the social entrepreneur's work is. Social entrepreneurship may have smaller capital requirements to commence than entrepreneurship. Entrepreneurship may have higher barriers to entry than social entrepreneurship. Entrepreneurship has higher entry barriers and takes more preparation. The entrepreneur may also have higher sunk cost. Social entrepreneurship has less of a competitive drive than entrepreneurship.

Awareness: Social entrepreneurs are more considerate and aware of people, social need, and social context, also social consequence. Social entrepreneurs don't put profit before people or social wealth. Social entrepreneurs may be better with the softer side of business than entrepreneurs. Social entrepreneurs may engage and interact with people better than the entrepreneur. Perhaps contrary to an entrepreneur, the social entrepreneur would see a person as a person and an asset. Social entrepreneurship is not afraid to get close and personal, whereas entrepreneurship prefers to keep it professional, transactional or detached. Social entrepreneurs connect with the heart, and involve the heart. Social entrepreneurship may be more aware of the relationships between products and people, and the affiliations of people with products. Entrepreneurs may be less attuned to people and their needs. Social entrepreneurs face greater scrutiny - they may be rejected more easily because they interact and function more closely with people.

\subsubsection{Competencies and Role Switching}

The social entrepreneur may be as much an entrepreneur as a social entrepreneur. Some may have no difficulty in operating in both areas. 
Despite the difficulties, not many social entrepreneurs would wish to switch from social entrepreneurship to entrepreneurship. The social entrepreneur may feel that it is hard to give up heart, when switching from social entrepreneurship to entrepreneurship. To the social entrepreneur, relationship may be more important than transaction. The successful entrepreneur may struggle to show and develop heart, when switching from entrepreneurship to social entrepreneurship. Some find it easy to straddle social entrepreneurship and entrepreneurship.

Switching from social entrepreneurship to entrepreneurship may mean the social entrepreneur must be less considerate of social need, social impact or social context. The social entrepreneur may also have to start serving different markets. Switching from entrepreneurship to social entrepreneurship may mean that the entrepreneur must be more considerate of social need, social impact, and social context. The entrepreneur may also need to be willing to sacrifice profit to do so. It may be difficult for the ordinary entrepreneur to recognise social need, and to induce social change, improvement or impact. The ordinary entrepreneur must be satisfied with less profit - to sacrifice profit for social impact. The social entrepreneur may have a broader perspective than the entrepreneur.

Still, it should not be too difficult to switch between social entrepreneurship and entrepreneurship, and vice versa. The entrepreneur may grow in terms of the social dimension, and decide to switch to social entrepreneurship for greater social connect, impact and change. The social entrepreneur may be over extended and applied - may have given too much of himself - and may wish to switch (back) to entrepreneurship. It may be easy for the social entrepreneur to take an ordinary product and service, and see how it can be extended to make it socially more relevant or impactful. A person who is socially groomed and matured in his education, would be able to commence with and make a success of social entrepreneurship. Many are trained in entrepreneurship, and later switch to social entrepreneurship, through increased awareness - they are 'awakened' to social entrepreneurship. Some remain social entrepreneurs, and have less potential or inclination to switch to entrepreneurship. Switching from social entrepreneurship to entrepreneurship, and vice versa, requires training and skills development.

\subsubsection{Economic Contribution of Social Entrepreneurship}

Both social entrepreneurship and entrepreneurship have capacity to create jobs. Social entrepreneurship has potential to contribute significantly to job creation, but mostly only through social transformation - when systems are changed, and when social entrepreneurship manages to change the system. Because social entrepreneurship straddles two objectives - social mission and financial sustainability - it has more opportunities, and can thus contribute more to job creation. Social entrepreneurship engages a greater population or audience, and can thus have bigger impact and job creation. There are more social opportunities than ordinary or conventional opportunities. It may be easier for social entrepreneurs, than for entrepreneurs, to start. Social entrepreneurial innovation may be easier than entrepreneurial innovation. Social entrepreneurs may have broader perspective and lower barriers to entry.

Social entrepreneurship has greater potential, because it believes in collaboration and resource sharing, and is less concerned about protecting profit and proprietary technology and assets. This may make social entrepreneurship more innovative and dynamic. Conversely, entrepreneurship can be more self-sufficient than social entrepreneurship. Social entrepreneurship can be more limited by finances than entrepreneurship. In this sense, entrepreneurship, its growth, and its extent, is less constrained than social entrepreneurship. Social entrepreneurship creates more hope and purpose jobs, than livelihood jobs. Social entrepreneurship finds it more difficult to show profit, and jobs created do not pay as well as entrepreneurship. Furthermore, there are generally more entrepreneurs and entrepreneurial ventures, than social entrepreneurs and social entrepreneurial ventures. Entrepreneurship has greater contribution to production and output than social entrepreneurship.

Social entrepreneurship can achieve social multiplication, making it an effective and cheap solution. Similar to an ordinary economic multiplier, social multiplication refers to multiplication of and through investment, (but) at a social level. This then generally translates to economic growth and development, given and through the relationship between social development and economic development.

\subsubsection{The Contribution of Social Entrepreneurship to Entrepreneurship}

Social opportunities that are exploited, can lead to opportunities for entrepreneurship. Social entrepreneurship can unlock and pave the way for unconventional opportunities normally not visible to ordinary entrepreneurship.

Social entrepreneurship can impact personal development, and that in turn can impact economic and entrepreneurial activity. The social entrepreneur may broaden the perspective of entrepreneurs and business to not only focus on profit, but to incorporate social responsibility or impact into their value proposition. Social 
entrepreneurship is seen as the future of entrepreneurship - social entrepreneurship has greater scope and ambition than entrepreneurship. By broadening their value propositions, or value base/ definition, social entrepreneurs can increase opportunities for entrepreneurs. Social entrepreneurship may directly or indirectly contribute to entrepreneurship. For example, some social entrepreneurs may wish to transfer, train and develop entrepreneurship skills, as part of their social impact: teaching entrepreneurship to others, as part of social impact and upliftment. This will mostly indirectly contribute to entrepreneurship. For social entrepreneurship to directly contribute to entrepreneurship, social entrepreneurship must change (the) business conditions, or increase economic activity.

Social entrepreneurs may have greater social and aesthetic awareness and appreciation than entrepreneurs, and can unlock greater value this way. It may be easier for social entrepreneurs to impact perspective, worldview, or culture, than entrepreneurs. Entrepreneurs may lack social perspective, and may miss opportunities this way. Entrepreneurs also don't consider first investing in others, which is taking more of a long term perspective. Entrepreneurship narrowly focuses on profit, and generally the shortest way to it. In a business context, social entrepreneurship rather focuses on profit through people, than profit at the cost of people. People are seen as assets and with value. It focuses on productivity, rather than compliance. Entrepreneurship may more readily adhere to a mindset and philosophy of exploiting people for profit. Social entrepreneurship focuses on responsibility, accountability, personal development, motivation and reward. Entrepreneurship puts profit before development, and this can lead to profit at the cost of people. Social entrepreneurship challenges entrepreneurship to a broader definition of success, and thus to a broader focus. Social entrepreneurship challenges the way entrepreneurship traditionally thinks of business. Social entrepreneurship challenges and disproves the belief of entrepreneurship that capital is necessary to venture. Social entrepreneurs can start opportunities with very little or no capital.

There are strong similarities between social entrepreneurship and entrepreneurship, particularly in terms of skills and management. Social enterprises run very much like ordinary enterprises. Because of the similarities, there is a lot that is transferable between social entrepreneurship and entrepreneurship. Businesses have become more socially conscious, and have incorporated and merged profit with purpose, social mission, or social impact more. There is a lot the commercial sector has learned from the social enterprise sector. Companies are moving from doing bad and simply covering it up with CSR, to becoming a lot more socially responsible. Social responsibility and impact are engrained into the DNA and culture of organisations a lot more - it has become far more mainstream. Social entrepreneurship has influenced, shaped, and expanded the mindset and thinking of business. Businesses have come to realize that they can build competitive advantage around social impact, and that social impact can actually increase and expand their value proposition and brand.

\section{Discussion}

\subsection{What are the objectives of social entrepreneurship? How does social entrepreneurship thinking relate to entrepreneurship?}

Social entrepreneurs have a strong focus on social impact, and consequently act as prominent change agents. Profit is not the primary objective of social entrepreneurs, and they can comfortably straddle profit and social impact. Social entrepreneurs are socially responsible: they believe in both social upliftment - helping others - and social independence - not depending on others for personal well-being, and not creating dependencies.

The social entrepreneur wants to bring about positive social impact, transformation, and change, and wants to uplift communities. Making a change and impacting people's lives is as important to the social entrepreneur as making a profit. The social entrepreneur generally sees a profit-only focus, as not sustainable. The social entrepreneur balances between social impact and sustainability.

Many social entrepreneurs see social transformation as everyone's responsibility. Social organization and governance are the responsibility of every individual, not simply government alone. Individuals should not look to government to solve their problems, instead they should be a lot more socially responsible. Social improvement or impact will and can only be achieved, if there is social transformation. Social entrepreneurs have a particular, additional, extra impact to drive social transformation.

Social entrepreneurship is not motivated by politics, and does not necessarily subscribe to an economic ideology. Social entrepreneurship is more broad and holistic in scope. Social entrepreneurship successfully combines financial objectives, and welfare and social objectives, without neglecting either.

\subsection{How do social entrepreneurs identify opportunities and incorporate innovation? How}




\section{does it relate to and compare with entrepreneurship?}

Social entrepreneurs generally encounter and thus recognize opportunities, rather than actively search for opportunities. This is likely due to the nature of social entrepreneurship work and solutions. A number of contact points, means and mediums allow the social entrepreneur to encounter and recognize opportunities. There may equally be windows the social entrepreneur may look through, to evaluate social health, and thus discover opportunities. Social opportunities differ on a number of factors, dimensions and aspects. There are both strong similarities and differences between social entrepreneurship and entrepreneurship opportunities. Both extensively build on and incorporate principal innovation and creative problem solving, and compare in terms of proposing and advancing solutions. At the same time, social entrepreneurship has very distinct dimensions, particularly in terms of social ills and social impact. The proactiveness and innovativeness of social entrepreneurship are important aspects and concepts. Similar to entrepreneurship, it may be equally possible, desirable and rewarding for social entrepreneurship to be radical and disruptive, although this looks and realizes somewhat differently for social entrepreneurship - the levers and buttons of radicality and disruption may be different for social entrepreneurship, than entrepreneurship.

\section{Opportunity recognition}

Most social entrepreneurs do not go looking for social problems to work on, they react to an event or condition that they experience or become aware of.

The social entrepreneur may identify social entrepreneurial opportunities through: social interactions, his interests, his knowledge base and experience, observations he makes, his personal needs, following the work of others, his network, and his context or environment, etc. Social trends and social movements may point to social forces, and can thus point out social opportunities.

Most successful social entrepreneurs engage personally with the work they do, and often build on their passion and interests.

When developing solutions for social problems, the social entrepreneur makes an effort to understand the social problem and its context. Simply coming up with an idea is not enough, the social entrepreneur engages the context to make his idea work.

Social entrepreneurial opportunities differ in their solutions, objectives, area of focus, social context, environment, support, and resources available. They also depend on the nature, preferences and passion of the social entrepreneur. Some social opportunities may have greater social need and as such, may be more difficult than others.

\section{Proactiveness}

Pure non-profit work tends to be more reactionary work, whereas social entrepreneurship targets sustained social impact or social change. Social entrepreneurship must be proactive to have really sustainable and impactful solutions.

\section{Disruption}

Social entrepreneurship is disruptive by nature, as it introduces and incorporates innovation and creativity to bring about social impact in a sustainable way. To be truly effective, social entrepreneurship should primarily seek to be disruptive, by effectively changing the system. Otherwise, social entrepreneurship is simply treating or alleviating symptoms. The social entrepreneur and his solutions need to be disruptive, in order to make significant social impact. Social entrepreneurship requires and builds on change. The social entrepreneur must not only come up with solutions that work, his solutions must be disruptive to truly contribute to social transformation.

\section{Innovativeness}

For social entrepreneurship to achieve social change and improvement, the social entrepreneur needs to think differently. The social entrepreneur needs to be creative and innovative in the way he tackles social problems.

\section{Solutions}

The social entrepreneur may learn from successful people, collaborate, research, and apply project management and problem solving skills, etc., to solve a social issue or problem he has identified.

Social projects go through a rigorous assessment and evaluation process. The social entrepreneur needs to, among other things, establish that the social problem exists and is recognized by those affected by it, understand and come up with an unique solution for the social problem, collaborate with others, develop a business model, and consider implementation of the solution.

\subsection{How is social entrepreneurship implemented? How does it relate to and compare with} entrepreneurship?

Implementation of social entrepreneurship can be considered and approached from both a micro level, 
and a macro level: how social entrepreneurs typically implement opportunities at a very individual level, as well as the overall extent and sophistication of social entrepreneurship opportunities and practice at a broader (national, etc.) level. Sustainability is a very important consideration for the social entrepreneur. Emphasis has shifted to self-sufficiency and financial sustainability. Startup is much the same for the social entrepreneur, compared to the entrepreneur, and the social entrepreneur generally requires business understanding and acumen just as much as the entrepreneur. Networking and collaboration extend the social entrepreneur. The social entrepreneur typically faces a number of challenges. Support further enables the social entrepreneur. Government can partner with social entrepreneurs more, to fix social ills and problems, but should step back, and must first truly understand social entrepreneurship. Corporations too can partner with social entrepreneurs more. This also requires more of a culture and perspective shift. There are a number of clear developments in social entrepreneurship practice. Evaluation and assessment of social impact is a pressing issue within social entrepreneurship.

\section{Sustainability}

The social entrepreneur should focus both on social impact and financial sustainability. To be successful, the social entrepreneur needs to be self-sufficient. A true social entrepreneur is self-sustainable, and does not depend or rely on grants and donations. The social entrepreneur should not plan to depend or rely on donations, etc to fund his social enterprise, but should plan to be financially sustainable. To be sustainable, the social entrepreneur needs to have positive social impact, and to recuperate cost through some way. The more radical the social entrepreneur is, the more likely he is to have sustainable social impact, and thereby survive.

\section{Startup}

The social entrepreneur should understand both the business side and the social side of the enterprise. Starting a social enterprise is similar to starting an entrepreneurial business or venture, in that it requires generating a business model, and answering key questions regarding the social venture. Additionally, it requires the social entrepreneur to be patient and innovative. The social entrepreneur must not be afraid to try, to learn, and to persevere.

While the setup of a social enterprise depends much on the structure, nature or purpose of the social enterprise, a hybrid setup appears to be a good setup for social entrepreneurs. A non-profit setup is met with too much red tape and bureaucracy, while a more for-profit setup may allow the social entrepreneur more freedom.

\section{Network}

The social entrepreneur values his network. The social entrepreneur can source a lot of resources, help, support and collaboration through his network. Social entrepreneurs typically get along easily, are willing to collaborate and support one another, and are less likely to compete. They may however face challenges, such as their ideas being stolen, lack of funding, competition among some social entrepreneurs, and exploitation. Nonetheless, the social entrepreneur persists and perseveres.

\section{Evaluation}

Social entrepreneurship struggles to quantify and measure social value or impact. The social entrepreneur measures his social impact by his own social wealth and capital, and by the impact he has had on others. The enablement of people's individual agency may also be a key measure of the impact of social entrepreneurship work.

\section{Challenges}

There is a place or need for radical social entrepreneurship. However, it faces challenges, such as a lack of support; lack of awareness of, experience of, and exposure to social entrepreneurship; strong focus on (people's need for) monetary gain; legislation and corruption; to mention a few.

Factors hindering social entrepreneurship and its development include: a lack of support from government, poor access to funding opportunities and issues around financial setup, lack of awareness and education, and a general lack of support and buy in for social projects.

\section{Support and collaboration}

Social entrepreneurs need government, corporations and society to support them, participate, and collaborate with them, without government or corporations necessarily operating in the social entrepreneurship space themselves. Government and corporations can contribute more to social entrepreneurship.

Government: Government can better support social entrepreneurs. Government should not attempt to fix social problems and deficiencies on its own, it should rather create an enabling environment: Government and society should partner for social health. Government should truly understand social entrepreneurship, to really be able to support it.

Corporations: Social entrepreneurial opportunities in organizations are constrained. There is a lot still that corporations can do to contribute to social entrepreneurship. Although awareness and acceptance of social 
entrepreneurship in corporations are increasing, support for social entrepreneurs is limited. Corporations are increasingly more willing to collaborate and partner with social entrepreneurs, and are also increasing their social entrepreneurial resources, capabilities, and capacity.

\section{Developments}

Some of the developments in social entrepreneurship include: a growing interest in social entrepreneurship; an increase in work aimed at supporting and funding social entrepreneurship; a move towards sustainable social impact; an increase in social entrepreneurship vehicles, technology, digitization, and decentralization; economic conditions and the environment; women empowerment; a rise in public benefit processes; an increase in opportunities for social entrepreneurs; collaboration; and training and support for social entrepreneurs.

5.4. What is the relationship between social entrepreneurship and entrepreneurship? How does social entrepreneurship contribute to entrepreneurship? How do social entrepreneurs perceive their competencies as ordinary entrepreneurs?

Both entrepreneurship- and business-experience benefit the social entrepreneur. The social entrepreneur with strong business acumen, has a distinct advantage, particularly in terms of financial sustainability, because social enterprises are run as businesses just as much. Social entrepreneurship equally contributes to the economy, albeit somewhat differently. Social entrepreneurship can contribute to entrepreneurship, though the distinct perspective it provides. Organizations increasingly find that they can build competitive advantage around social impact and responsibility. Social entrepreneurship also contributes to economic development and activity, through personal development, and can precede entrepreneurship in this way.

Social entrepreneurship and entrepreneurship can be compared on a number of grounds, including the level of risk and the level of difficulty. Financial sustainability may make social entrepreneurship more difficult than entrepreneurship. Furthermore, the view is that it should not be too difficult for social entrepreneurs to switch to entrepreneurship, and vice versa. "Heart" - a focus on social impact - is a key determining factor in this regard. A focus on people and social impact are of course also what distinguish social entrepreneurship from entrepreneurship.

\section{Business acumen and experience}

Entrepreneurship and business experience can help the social entrepreneur. Business experience keeps the social entrepreneur focused, and helps him to be financially sustainable. Knowing how to run a business, allows the social entrepreneur to apply business principles, skills, and thinking to social entrepreneurship. This impacts his success. Doing business with a social mission in mind, is still doing business - social enterprises do not really differ from normal businesses.

\section{Impact}

Social entrepreneurship challenges that way entrepreneurship traditionally thinks of business and its definition of success. Social entrepreneurship contributes to entrepreneurship, by broadening the perspective of entrepreneurs, which invariably increases their opportunities.

The commercial sector has learned a great deal from the social enterprise sector. Companies have become more socially responsible, and have realized that they can build a competitive advantage around social impact.

Social entrepreneurship can increase economic activity, and in this way precede entrepreneurship.

\section{Economic contribution}

While social entrepreneurship has potential to contribute significantly to job creation, it does not necessarily have greater capacity to create jobs than entrepreneurship. Both social entrepreneurship and entrepreneurship have capacity to create jobs.

\section{Comparison}

Although there are some differences between social entrepreneurship and entrepreneurship, there remain a lot of common and similar concepts between the two, thus making it easy for some to straddle social entrepreneurship and entrepreneurship. Although switching from social entrepreneurship to entrepreneurship, and vice versa, may require training and skills development, it should not be too difficult to switch between the two.

Perhaps the greatest aspect that social entrepreneurship picks up, that entrepreneurship fails to recognize, is that social entrepreneurship has a greater focus on people and social contexts, as opposed to entrepreneurship, that focuses more on profit. Entrepreneurs may be less attuned to people and their needs.

Both social entrepreneurship and entrepreneurship have their inherent risk. Industry and context may dictate which is riskier: social entrepreneurship or entrepreneurship. 
Social entrepreneurship may be harder than entrepreneurship, because social entrepreneurship has a more difficult financial side - it is more difficult to sustain financially; it serves a dual, often contradicting, objective; it has to build a business model around a social problem; and the scale at which the social entrepreneur engages can add to its difficulty.

\section{Conclusion}

Social entrepreneurs have a strong focus on social impact, and consequently act as prominent change agents. Profit is not the primary objective of social entrepreneurs, and they can comfortably straddle profit and social impact. Social entrepreneurs are socially responsible: they believe in both social upliftment - helping others - and social independence - not depending on others for personal well-being, and not creating dependencies.

Social entrepreneurs generally encounter and thus recognize opportunities, rather than actively search for opportunities. This is likely due to the nature of social entrepreneurship work and solutions. A number of contact points, means and mediums allow the social entrepreneur to encounter and recognize opportunities. There may equally be windows the social entrepreneur may look through, to evaluate social health, and thus discover opportunities. Social opportunities differ on a number of factors, dimensions and aspects. There are both strong similarities and differences between social entrepreneurship and entrepreneurship opportunities. Both extensively build on and incorporate principal innovation and creative problem solving, and compare in terms of proposing and advancing solutions. At the same time, social entrepreneurship has very distinct dimensions, particularly in terms of social ills and social impact. The proactiveness and innovativeness of social entrepreneurship are important aspects and concepts. Similar to entrepreneurship, it may be equally possible, desirable and rewarding for social entrepreneurship to be radical and disruptive, although this looks and realizes somewhat differently for social entrepreneurship - the levers and buttons of radicality and disruption may be different for social entrepreneurship, than entrepreneurship.

Implementation of social entrepreneurship can be considered and approached from both a micro level, and a macro level: how social entrepreneurs typically implement opportunities at a very individual level, as well as the overall extent and sophistication of social entrepreneurship opportunities and practice at a broader level. Sustainability is a very important consideration for the social entrepreneur. Emphasis has shifted to selfsufficiency and financial sustainability. Startup is much the same for the social entrepreneur, compared to the entrepreneur, and the social entrepreneur generally requires business understanding and acumen just as much as the entrepreneur. Networking and collaboration extend the social entrepreneur. The social entrepreneur typically faces a number of challenges. Support further enables the social entrepreneur. Government can partner with social entrepreneurs more, to fix social ills and problems, but should step back, and must first truly understand social entrepreneurship. Corporations too can partner with social entrepreneurs more. This also requires more of a culture and perspective shift. There are a number of clear developments in social entrepreneurship practice. Evaluation and assessment of social impact is a pressing issue within social entrepreneurship.

Both entrepreneurship- and business-experience benefit the social entrepreneur. The social entrepreneur with strong business acumen, has a distinct advantage, particularly in terms of financial sustainability, because social enterprises are run as businesses just as much. Social entrepreneurship equally contributes to the economy, albeit somewhat differently. Social entrepreneurship can contribute to entrepreneurship, though the distinct perspective it provides. Organizations increasingly find that they can build competitive advantage around social impact and responsibility. Social entrepreneurship also contributes to economic development and activity, through personal development, and can precede entrepreneurship in this way.

Social entrepreneurship and entrepreneurship can be compared on a number of grounds, including the level of risk and the level of difficulty. Financial sustainability may make social entrepreneurship more difficult than entrepreneurship. Furthermore, the view is that it should not be too difficult for social entrepreneurs to switch to entrepreneurship, and vice versa. "Heart" - a focus on social impact - is a key determining factor in this regard. A focus on people and social impact are of course also what distinguishes social entrepreneurship from entrepreneurship.

\section{Future Research}

Future research can further consider the following:

- Social entrepreneurship and economic development: The impact of social entrepreneurship on 
economic development, particularly through personal development and social upliftment. Research can consider the degree and factors of success, as well as best practices in this regard.

- Social entrepreneurship and economic development: a number of social entrepreneurs have economic development aspirations and ambitions, and in this context, also mix social entrepreneurship and entrepreneurship. Research can specifically focus on how social entrepreneurs teach and instruct entrepreneurs and entrepreneurship. In particular, how social entrepreneurs and social entrepreneurship assert and advocate the aspirant entrepreneur should get off the ground, given social entrepreneurs' core competency of starting enterprises with very little resources.

- The commercialization of social entrepreneurship innovation.

- The resourcefulness of social entrepreneurs: As already mentioned, social entrepreneurs generally possess a core competency of starting enterprises with very little resources.

- Social impact, social responsibility, and competitive advantage: how organizations build and can build competitive advantage around social impact and social responsibility.

- Social impact measurement. Enhancing social impact measurement.

- Disruptive and radical social entrepreneurship: Further considering disruptive and radical social entrepreneurship as constructs, and the antecedents and factors thereof.

- (National) social entrepreneurship (development) metrics: A measure of an organization's or country's development, maturity and competency, in terms of social entrepreneurship.

- Government, corporations, and social entrepreneurship: government and corporate social entrepreneurship policy, programs, and implementation.

- Social multipliers, as it relates to social entrepreneurship work, social impact, and economic multipliers.

- The sophistication of entrepreneurs' social awareness and perspective, and the impact thereof on opportunities and opportunity recognition.

\section{References}

Abu-Saifan, S., 2012. Social entrepreneurship: definition and boundaries. Technology Innovation Management Review, 2(2).

Alvord, S. H., Brown, L. D., and Letts, C. W., 2004. Social entrepreneurship and societal transformation. Journal of Applied Behavioral Science, 40(3), pp.260-282.

Auerswald, P., 2009. Creating social value. Stanford Social Innovation Review.

Austin, J., Stevenson, H. and Wei-Skillern, J., 2006. Social and commercial entrepreneurship: same, different, or both?. Entrepreneurship theory and practice, 30(1), pp.1-22.

Borins, S., 2000. Loose cannons and rule breakers, or enterprising leaders? Some evidence about innovative public managers. Public Administration Review, 60(6), pp.498-507.

Bornstein, D., 2004. How to change the world: Social entrepreneurs and the power of new ideas. New York: Oxford University Press.

Boschee, J., 1998. Merging mission and money: A board member's guide to social entrepreneurship. [online] Available at: http://www.socialent.org/pdfs/MergingMission.pdf [Accessed 18 June 2019].

Boschee, J. and McClurg, J., 2003. Toward a better understanding of social entrepreneurship: Some important distinctions. [online] Available at: https://www.law.berkeley.edu/phpprograms/courses/fileDL.php?fID=7289 [Accessed 18 June 2019].

Certo, S.T. and Miller, T., 2008. Social entrepreneurship: Key issues and concepts. Business horizons, 51(4), pp.267-271.

Dacin, P.A., Dacin, M.T. and Matear, M., 2010. Social entrepreneurship: Why we don't need a new theory and how we move forward from here. The academy of management perspectives, 24(3), pp.37-57.

Dacin, M.T., Dacin, P.A. and Tracey, P., 2011. Social entrepreneurship: A critique and future directions. Organization science, 22(5), pp.1203-1213.

Dees, G., 1994. Social enterprise: Private initiatives for the common good. Working Paper Series No. 9-395116, Harvard Business School.

Dees, J.G., 2001. The meaning of social entrepreneurship. Center for the Advancement of Social Entrepreneurship.

Dees, J.G., 2007. Taking social entrepreneurship seriously. Society, 44(3), pp.24-31.

Drayton, W., 2002. The citizen sector: Becoming as entrepreneurial and competitive as business. California management review, 44(3), pp.120-132. 
Guclu, A., Dees, J.G. and Anderson, B.B., 2002. The process of social entrepreneurship: Creating opportunities worthy of serious pursuit. Center for the advancement of Social Entrepreneurship, 1, pp.1-15.

Harding, R., 2004. Social enterprise: the new economic engine? Business Strategy Review, 15(4), pp.39-43.

Hartigan, P., 2006. It's about people, not profits. Business Strategy Review, 17(4), pp.42-45.

Haugh, H., 2007. Community-led social venture creation. Entrepreneurship theory and practice, 31(2), pp.161-182.

Hockerts, K., 2006. Entrepreneurial opportunity in social purpose business ventures. In Social entrepreneurship (pp. 142-154). Palgrave Macmillan, London.

Johnson, S., 2000. Literature review on social entrepreneurship. Canadian Centre for Social Entrepreneurship, 16, p.23.

Korosec, R.L. and Berman, E.M., 2006. Municipal support for social entrepreneurship. Public administration review, 66(3), pp.448-462.

Light, P.C., 2006. Reshaping social entrepreneurship. Stanford Social Innovation Review, 4(3), pp.47-51.

Mair, J. and Marti, I., 2006. Social entrepreneurship research: A source of explanation, prediction, and delight. Journal of world business, 41(1), pp.36-44.

Mair, J. andNoboa, E., 2006. Social entrepreneurship: How intentions to create a social venture are formed. In Social entrepreneurship (pp. 121-135). Palgrave Macmillan, London.

Massetti, B.L., 2008. The social entrepreneurship matrix as a" tipping point" for economic change. Emergence: Complexity and Organization, 10(3), p.1.

Mulgan, G., 2006. The process of social innovation. Innovations: technology, governance, globalization, 1(2), pp.145-162.

Roberts, D. and Woods, C., 2005. Changing the world on a shoestring: The concept of social entrepreneurship. University of Auckland Business Review, 7(1), pp.45-51.

Robinson, J., 2006. Navigating social and institutional barriers to markets: How social entrepreneurs identify and evaluate opportunities. In Social entrepreneurship (pp. 95- 120). Palgrave Macmillan, London.

Roper, J. and Cheney, G., 2005. The meanings of social entrepreneurship today. Corporate Governance: The international journal of business in society, 5(3), pp.95-104.

Short, J.C., Moss, T.W. and Lumpkin, G.T., 2009. Research in social entrepreneurship: Past contributions and future opportunities. Strategic entrepreneurship journal, 3(2), pp.161-194.

Thompson, J., Alvy, G., and Lees, A., 2000. Social entrepreneurship: A new look at the people and the potential. Management Decision, 38(5), pp.328-338.

Townsend, D.M. and Hart, T.A., 2008. Perceived institutional ambiguity and the choice of organizational form in social entrepreneurial ventures. Entrepreneurship theory and practice, 32(4), pp.685-700.

Zahra, S.A., Gedajlovic, E., Neubaum, D.O. and Shulman, J.M., 2009. A typology of social entrepreneurs: Motives, search processes and ethical challenges. Journal of business venturing, 24(5), pp.519-532. 